\title{
Alman Hukukuyla Karşılaştırmalı Yardım Etme Hareketleri
}

\author{
The Acts of Aiding in Compare with German Law
}

\section{Muhammed DEMİREL ${ }^{1}$}

\author{
${ }^{1}$ Dr., İstanbul Üniversitesi Hukuk Fakültesi Ceza ve Ceza Muhakemesi Hukuku Anabilim Dalı, İstanbul, Türkiye
}

\section{öz}

Türk Ceza Kanunu (TCK)'nda "Suça Iş̧tirak" başığı altında düzenlenen yardım etme, kanunun 39'uncu maddesinde hüküm altına alınmış, bu kapsamda nelerin yardım etme olduğu açıkça ve sınırlı bir şekilde belirlenmiştir. Bunlar; suç işlemeye teşvik etmek veya suç işleme kararını kuvvetlendirmek veya fiilin işlenmesinden sonra yardımda bulunacağını vaat etmek, suçun nasıl işleneceği hususunda yol göstermek veya fiilin işlenmesinde kullanılan araçları sağlamak, suçun işlenmesinden önce veya işlenmesi sırasında yardımda bulunarak icrasını kolaylaştırmaktır. Bunların dışında, gerek maddede gerekse madde gerekçesinde bu yardım türlerinden ne anlaşılması gerektiğine yer verilmemiştir. Bu hareketler ve durumlar, genel olarak gayet açık ve anlaşıır gibi görünse de gerek birbirleri arasındaki ince ayrımlar, gerekse azmettirme hareketi ve müşterek faillik kapsamında gerçekleştirilen hareketlerle ayrımları noktasında özel bir incelemenin yapılmasını zaruri hale getirmektedir. Buna göre müşterek faillikle yardım etme ve keza azmettirmeyle yardım etme arasındaki ayrımın hangi ölçütlere göre yapılacağı, nitekim olay yerinde gözcülük yapan kişinin müşterek fail mi yoksa yardım eden mi olduğu bu sorunlara verilebilecek örneklerden birkaçıdır. İşte bu sorunlar nedeniyle konu, detaylı bir şekilde irdelenmelidir. Bu çerçevede Alman Ceza Kanunu'ndaki yardım etmeye ilişkin düzenleme de (§ 27) dikkate alınmalıdır. Zira Alman Ceza Kanunu'nda yardım etme durumları açıcça düzenlenmiş olmasa ve bu konu doktrine bırakılmış olsa da doktrindeki görüş ve tartışmalar, Türk hukukuna yol gösterecek niteliktedir. İşte bu makalede, Alman hukuku ile karşılaştırmalı olarak bu yardım etme hareketleri özel olarak irdelenmekte, bununla birlikte Türk mahkeme kararları üzerinden de bir inceleme yapılmaktadır.

Anahtar Kelimeler: Yardım etme, suça teşvik etme, suç işleme kararını kuvvetlendirme, suça araç sağlama, suçun işlendiği yerde bulunma, gözcülük, manevi anlamda yardım etme

\section{ABSTRACT}

A crime can only be committed by the perpetrator. But besides the perpetrator can participate in a crime and also be found criminally responsible. Participation can include acts such as making the decision to commit the crime, giving a pistol to another person for the commission of a crime, and keeping watch while a crime takes place. Someone who provides support during or for the commission of a crime is not responsible as a perpetrator, but is responsible as a solicitor, aider, or inciter, depending on the actions of the perpetrator.

Criminal liability for aiders and inciters is regulated under the title "Participation in Crime" in the Turkish Criminal Code. The regulation for aiders is formulated in Article 39, under the title of "Aiding." This regulation determines the acts that can be considered aiding. This regulation identifies the acts of aiding as limited and serial. These acts include the following: soliciting a person for commission of a crime, supporting a person's decision to commit a crime, guaranteeing help to someone after commission of a crime, providing ideas about how the crime should be committed, supplying the necessary tools to be used during commission of a crime, or rendering support before and during the commission of a crime in order to simplify the intended act. In this essay, we analyse only the acts of aiding in a crime.

Keywords: Turkish Criminal Code, German Criminal Code, Perpetrator, Accomplice, Aider, Attempted Aider, Inciter, Keep Watch During a Crime, Acts of Aiding, Solicit for Commission of a Crime, Support a Decision to Commit a Crime, Provide Ideas About How to Commit a Crime 


\section{EXTENDED ABSTRACT}

In the criminal code, a crimes is defined such that it can only be committed by a perpetrator. Punishing those who provide support for the commission of a crime but do not fulfil certain typical acts stipulated in the code requires an additional condition: this is called the accessory principle. In this context, the criminal liability of solicitors, aiders, or inciters to a crime depends on that of the perpetrator. Criminal liability for aiders and inciters is regulated under the title "Participation in Crime" in the Turkish Criminal Code. The regulation for aiders is formulated in Article 39, under the title of "Aiding." This regulation determines which acts are considered aiding. According to this regulation, a person aiding another person in the commission of an offense can be sentenced to heavy life imprisonment, from 15 to 20 years, or to imprisonment from 10 to 15 years, if the perpetrator is subject to life imprisonment. Finally, this regulation defines the acts of aiding as limited and serial. These acts read as follows: to solicit a person for commission of a crime, to support a person's decision to commit crime, to provide a guarantee of help after commission of crime, to provide ideas about how the crime should be committed, to supply the necessary tools to be used during commission of crime, or to render support before and during the commission of a crime in order to simplify the intended act.

The legislative reasoning for this article does not define the scope of the aiding act. The definition of this condition is largely open to what it means to behave as an aider. There is also a similar influencing regulation in the 765 numbered Turkish Criminal Code (the former Code). In spite of the new Code's explicitness, some problems arise under this article. Some of these read as follows: What are the differences between inciter and aider or accomplice and aider? Is someone who keeps watch during a crime considered an aider or an accomplice? This issue is important and must be handled carefully and in detail. In addition, the aiding regulation of the German Criminal Code (paragraph 27) must be taken into consideration, because this regulation (\$27) differs from Article 39. The difference is that Article 39 clarifies the acts, whereas $\$ 27$ does not. In German law, aiding acts are not defined clearly; this subject has been dealt with in doctrine. Comparing Turkish with German law on this subject is important in order to bring light to Turkish law. In particular, we emphasize how we deal with this subject in the following table, which contains the special systematic steps of aiding. Finally, in this essay, we analyse only aiding acts (Number 2 in table). 


\section{THE SYSTEMATIC REVIEW OF AIDING}

\section{A. Material Element}

1. Perpetrator's Act Committed Intentionally and Contrary to the Laws

TYPICALITY

2. Aiding Acts

B. Moral Element

Double Complicity Intent

C. Unlawfulness Element

\section{Genel Olarak}

Yardım etme, Türk Ceza Kanunu'nun "Suça İştirak" başlığını taşıyan dördüncü bölümü altında "Yardım Etme" başlığıyla 39'uncu maddesinde düzenlenmiştir. Bu düzenlemede suçun işlenmesine yardım eden kişiye, işlenen suçun ağırlaştırılmış müebbet hapis cezasını gerektirmesi halinde, on beş yıldan yirmi yıla; müebbet hapis cezasını gerektirmesi halinde, on yıldan on beş yıla kadar hapis cezası verileceği, diğer hallerde cezanın yarısı indirileceği, ancak bu durumda verilecek cezanın sekiz yılı geçemeyeceği belirtilmiştir. Hükmün devamında ise kişinin hangi hallerde işlenen suçtan yardım eden sıfatıyla sorumlu tutulacağı sıralı ve sınırlı bir şekilde ifade edilmiştir. Buna göre bir kimsenin yardım etmeden sorumlu tutulabilmesi için, a) Suç işlemeye teşvik etmek veya suç işleme kararını kuvvetlendirmek veya fiilin işlenmesinden sonra yardımda bulunacağını vaat etmek, b) Suçun nasıl işleneceği hususunda yol göstermek veya fiilin işlenmesinde kullanılan araçları sağlamak, c) Suçun işlenmesinden önce veya işlenmesi sırasında yardımda bulunarak icrasını kolaylaştırmak şeklindeki durumlardan birinin gerçekleşmesi gerekir. Bunun dışında madde gerekçesinde, bu davranışlarla ilgili herhangi bir bilgiye yer verilmemiş, maddedeki ifadelerle yetinilmiştir. Bu, söz konusu durumlar kapsamında yer alabilecek davranışlardan ne anlaşılması gerektiğinin büyük ölçüde açık olmasından kaynaklanmaktadır. Elbette düzenlemenin 765 sayılı TCK' daki yardım etmeye ilişkin hükümle büyük oranda benzerlik göstermesinin de etkisi gözden uzak tutulmamalıdır ${ }^{1}$.

1 Veli Özer Özbek/Koray Doğan/Pınar Bacaksız/İlker Tepe, Türk Ceza Hukuku Genel Hükümler, 8. Baskı, Seçkin, Ankara 2017, s. 526; Ali Kemal Yıldız, 5237 Sayılı Türk Ceza Kanunu, İstanbul Barosu Yayınları, İstanbul 2007, s. 122; Zeki Hafızoğlulları/Muharrem Özen, Türk Ceza Hukuku Genel Hükümler, 2. Bası, US-A Yayıncılık, Ankara 2010, s. 372. 
Buna rağmen belirtilen davranışların, azmettirme kapsamında suç işleme kararının oluşturulması ya da müşterek faillik kapsamında suçun birlikte işlenmesi şeklindeki davranışlardan ayırt edilmesi, gözcülük gibi birtakım hareketlerin bu davranışlar altında telakki edilip edilmeyeceği hususlarının özel olarak irdelenmesi yönünde bir gereklilik bulunmaktadır. Dolayısıyla da yardım etme hareketlerine ilişkin kanundaki açıklığa rağmen bu konuda dahi doktrinel anlamda tartışmaların ortaya çıktığı görülmekte, bu da konunun, incelemeye değer bir yönünün olduğunu göstermektedir.

Bu durum, Alman ceza hukukunda daha ayrı bir önem arz etmektedir. Zira Alman Ceza Kanunu'nun 27'nci paragrafinda düzenlenen yardım etme düzenlemesi altında bir başkasının kasıtlı olarak işlediği hukuka aykırı fiile kasıtlı olarak yardım sağlayan kişinin yardım eden olarak sorumlu tutulacağı belirtilmiş ve düzenlemede yardım sağlamaktan ne anlaşılması gerektiği, hangi davranışların yardım sağlama olduğu hususlarına Türk ceza hukukunda olduğu gibi bir açıklık getirilmemiştir. Bu açıdan Alman hukukunda, bu konu tamamen doktrine bırakılmıştır². Dolayısıyla Alman hukukunda failin işlediği suça yardım etmeden ne anlaşılacağının ortaya konulması, Alman literatürünün iyi bir şekilde incelenmesini, bununla birlikte yargı kararlarının da gözden kaçırılmamasını gerekli hale getirmektedir. İşte çalışmamızda da bu hususlar, Türk ve Alman doktriniyle mahkeme kararları birlikte dikkate alınarak bir inceleme yapılmıştır.

Tüm bunların yanında yardım etmenin her iki hukuk düzeninde de maddi yardım ve manevi yardım adı altında incelendiği, bu şekilde bir kolaylık sağlanmaya

2 Martina Baunack, Grenzfragen der strafrechtlichen Beihilfe, Duncker \& Humblot, Berlin 1999, s. 97; Mahmut Koca/İlhan Üzülmez, Ceza Hukuku Genel Hükümler, 10. Baskı, Seçkin, Ankara 2017, s. 488, dpn. 1651. Dolayısıyla Alman Ceza Kanunu'ndan farklı olarak TCK md. 39 hükmüyle yardım etme hareketlerinin tek tek gösterilmesinin kanunilik ilkesinin bir gereği olduğu yönündeki görüşün yerindeliği (Hamide Zafer, Ceza Hukuku Genel Hükümler, 6. Bası, Beta, İstanbul 2016, s. 478) şüphelidir. O kadar ki Alman Ceza Kanunu'ndaki bu düzenlemeye göre "yardım etme” kavramının kapsamının oldukça geniş olduğuna, bu nedenle de bilhassa nedensellik hususunda kanunilik prensibiyle bağlantılı olarak sorunların ortaya çıktığına işaret edilmesine rağmen bu durumun yardım etme hareketlerinin kanunda sayılmamasından bahsedilmemiş, bilakis manevi yardım etmenin kendi yapısından, kapsamın genişliğinden söz edilmiştir (Aristoteles Charalambakis, "Zur Problematik der psychischen Beihilfe", FS-Roxin, 2001, s. 625). Bununla birlikte bu hareketlerin kanunda tahdidi şekilde gösterilmesi karşısında bu davranışlar dışında kalan bir hareketle de yardım etmeden sorumluluk yoluna gidilememesi, kanunilik ilkesinin bir gereği olarak telakki edilebilir (Fatih Selami Mahmutoğlu/Serra Karadeniz, Türk Ceza Kanunu Genel Hükümler Şerhi, Beta, İstanbul 2017, s. 918). Yani bu hareketlerin kanunda gösterilmesi, bir zorunluluk değildir ve bu bakımdan da kanunilik ilkesinin bir gereği olarak görülemez. Buna karşılık TCK'da olduğu gibi şayet bu hareketler tek tek gösterilmişse bu hareketler dışında yardım etmenin kabul edilmemesi, kanunilik ilkesinin beraberinde getirdiği bir husus olarak görülecektir. 
çalışıldığı görülmektedir ${ }^{3}$. Bu nedenle de inceleme yapılırken yardım etme, maddi anlamda yardım etme ve manevi anlamda yardım etme şeklinde tasnif edilmiş, bu üst başliklar altında irdeleme yoluna gidilmiştir.

İncelemeye geçilmeden evvel özellikle vurgulamak gerekir ki, bir kimsenin yardım eden olarak sorumlu tutulması ve cezalandırılması, her ne kadar yardım hareketlerinin gerçekleştirilmesine bağlı olsa da salt bu hareketlerin gerçekleştirilmesiyle de ulaşılabilecek bir sonuç değildir. Bu hareketler, yardım etmenin maddi unsurları kapsamında yalnızca yardım etme hareketini oluşturmaktadır. Şu halde yardım etme hareketleri, yardım etmenin ilk şartı olup ${ }^{4}$ tek başına da yeterli değildir. Buna mukabil herhangi bir yardım etme hareketi gerçekleştirilmediğinde de cezalandırılabilir bir yardım etmeden söz edilemez. Nitekim hırsızlık suçu sonucunda elde edilen paralardan, bu suçtan habersiz ve de bağımsız bir başka kişinin yararlanması halinde yardım etme hareketinin varlığından bahsedilemez ${ }^{5}$. Bu noktada yardım etme hareketi bulunmadığından kişinin kastını ve fiilinin hukuka aykırılığını dahi incelemeye gerek bulunmamaktadır.

Şu halde bu hareketlerin, bir şeriklik türü olan yardım etme sistematiğinde tam olarak nerede konumlandığının tespit edilmesi gerekmektedir. Şöyle ki, tabloda da görüleceği üzere yardım etme de faillik gibi tipiklik ve hukuka aykırılık şeklinde ayrılmış bir sistematik üzerinden irdelenebilir. Bununla birlikte yardım etme, ceza kanununun özel hükümlerindeki suç tipleri üzerinden gerçekleşmediğinden ve incelenmediğinden, kanunun genel hükümlerinde düzenlenen ve ferî niteliği haiz bir

3 Türk doktrini için bkz. İzzet Özgenç, Türk Ceza Hukuku Genel Hükümler, 13. Bası, Seçkin, Ankara 2017, s. 553; Koca/Üzülmez, s. 488; M. Emin Artuk/Ahmet Gökcen/A. Caner Yenidünya, Ceza Hukuku Genel Hükümler, 10. Bası, Adalet, Ankara 2016, s. 666; M. Emin Artuk/Ahmet Gökcen/M. Emin Alşahin/ Kerim Çakır, Ceza Hukuku Genel Hükümler, 11. Baskı, Adalet, Ankara 2017, s. 677; Özbek/Doğan/ Bacaksı/Tepe, s. 525; Nur Centel/Hamide Zafer/Özlem Çakmut, Türk Ceza Hukuku Genel Hükümler, 9. Bası, Beta, İstanbul 2016, s. 499; Yıldız, s. 122; Mustafa Ruhan Erdem, "Yeni TCK'da Faillik ve Suç Ortaklığı”, HPD 2005, S. 5, s. 213; Hakan Hakeri, Ceza Hukuku Genel Hükümler, 20. Baskı, Adalet, Ankara 2017, s. 589; Zafer, s. 478; Doğan Soyaslan, Ceza Hukuku Genel Hükümler, 7. Bası, Yetkin, Ankara 2016, s. 483; Osman Yaşar/Hasan Tahsin Gökcan/Mustafa Artuç, Yorumlu-Uygulamalı Türk Ceza Kanunu, C. I, 2. Baskı, Adalet, Ankara 2014, s. 1156; Mahmutoğlu/Karadeniz, s. 919. Alman doktrininde bu hususta bir oybirliği bulunmakla birlikte bir kısım örnek için bkz. Baunack, s. 97; Jürgen Baumann/Ulrich Weber/Wolfgang Mitsch/Jörg Eisele, Strafrecht Allgemeiner Teil, 12. Auflage, Gieseking, Biefeld 2016, § 26 kn. 98; Walter Gropp, Strafrecht Allgemeiner, 4. Auflage, Springer, Heidelberg 2015, § 10 kn. 292; Eric Hilgendorf/Brian Valerius, Strafrecht Allgemeiner Teil, 2. Auflage, C. H. Beck, München 2015, § 9 kn. 147; Fritjof Haft, Strafrecht Allgemeiner Teil, 9. Auflage, C. H. Beck, München 2004, s. 220. Esasında bu şekilde maddi ve manevi yardım ayrımına yer verilmesi, Alman Ceza Kanunu'nda mevcut düzenleme öncesi "sözle veya fiille" yardımdan bahsedilmesine dayandığını belirtmek yanlış olmayacaktır. Bkz. Baumann/Weber/Mitsch/Eisele, § 26 kn. 98.

4 Koca/Üzülmez, s. 487; Yaşar/Gökcan/Artuç, C. I, s. 1155.

5 Hakeri, s. 589. 
düzenleme olduğundan kendine has bir sistematik üzerinden ele alınacaktır. Dolayısıyla yardım etmenin maddi unsuru altında, $i$. Failin kasıtlı ve hukuka aykırı olarak işlenmiş fiili, ii. "Inceleme konumuz olan yardım etme hareketleri yer alacakken yardım etmenin manevi unsuru altında ise çifte şeriklik kastı yer alacaktır (Bakınız Tablo) ${ }^{6}$. İşte bu çalışmadaki inceleme, tam olarak yardım etmenin maddi unsurları altındaki yardım etme hareketleri üzerine olacaktır.

\section{YARDIM ETMENIN SISTEMATIK İNCELEMESİ}

\section{A. Maddi Unsur}

1. Failin kasıtlı ve hukuka aykırı olarak işlenmiş fili

2. Yardım Etme Hareketleri

B. Manevi Unsur

Çifte Şeriklik Kastı

C. Hukuka Aykırılık

\section{TİPİKLİK}

\section{Yardım Etme Türleri}

\subsection{Maddi Anlamda Yardım Etme}

Hem fiilin işlenmesinde zorunlu olan veya en azından fiilin işlenmesini kolaylaştıran araçların temin edilmesi hem de gözcülük gibi başka bedensel aktivitelerle işlenen fiile doğrudan etki oluşturacak türde bir katkı sağlanması şeklinde tezahür eden ${ }^{7}$ maddi anlamda yardım etme ${ }^{8}$, suçun işlenmesinde kullanılacak araçların sağlanması ve suç işlenmeden önce veya suçun işlenmesi esnasında faile

6 Tablo, Hoffmann-Holland ve Satzger'den alınmıştır. Bkz. Klaus Hoffmann-Holland, Strafrecht Allgemeiner Teil, 3. Auflage, Mohr Siebeck, Tübingen 2015, kn. 560; Helmut Satzger, "Teilnehmerstrafbarkeit und 'Doppelvorsatz", Jura 2008, s. 516.

7 Claus Roxin, "Was ist Beihilfe?”, FS-Miyazawa, 1995, s. 505; Baunack, s. 97; Baumann/Weber/Mitch/ Eisele, § 26 kn. 99. Bedensel katkıların, manevi bir etki oluşturması durumunda maddi yardımdan değil, manevi yardımdan söz edilecektir. Dolayısıyla bedensel katkıların, Roxin ’in belirttiği gibi maddi yardım olarak nitelendirilebilmesi için etkisinin de maddi alanda kalması, manevi alana geçmemesi gerekir. Şu halde bir davranışın salt bedensel oluşundan hareketle yardımın maddi mi yoksa manevi mi olduğu yönünde bir tespit yapılması makul bir yol olmayacaktır. Önemli olan davranışın niteliğinden ziyade davranışın oluşturduğu etkidir.

8 Alman literatüründe bazı görüşler tarafından "teknik anlamda yardım” olarak ifade edilmektedir (Klaus Geppert, "Die Beihilfe", Jura 1999, s. 267; Baunack, s. 97; Charalambakis, s. 634; Haft, s. 222). Buna rağmen teknik yardım ifadesi, genel olarak manevi yardım etme kapsamında suçun nasıl işleneceği hususunda yol gösterme için kullanılmaktadır. Zira bu yardım etme davranışı içerisinde faile fiilin nasıl işleneceği hususunda teknik bazı bilgiler verilmektedir (Charalambakis, s. 634). Bu konuda ayrıntılı bilgiler için bkz. 
yardımda bulunarak fiili icrasını kolaylaştırma şeklinde söz konusu olabilir99 .

\section{a. Suçun İşlenmesinde Kullanılacak Araçların Sağlanması}

Bu çerçevede ilk olarak suçun işlenmesinde kullanılmak üzere faile araç temin edilmesi, kişide suç işleme kararının oluşmasına neden olmaması kaydılla ${ }^{10}$ maddi yardım olarak kabul edilecektir. Bu konudaki en basit ve sıklıkla karşılaşılan örnek, bir kimseyi öldürme düşüncesi olan faile, fiili işlemesi için silah temin edilmesidir ${ }^{11}$. Söz konusu silahla suçun işlenmiş olması halinde silahı temin eden kişinin bu hareketinin meydana gelen netice açısından nedenselliğini izah etmeye gerek dahi bulunmamaktaysa da bazı yazarlar tarafından belirtildiği gibi ${ }^{12}$ buradaki hareketin cezalandırılmasındaki gerekçe, her durumda bu araç olmaksızın fiilin gerçekleştirilemeyecek olması yönünde bir argüman olamaz. Zira bir köyde B'yi öldürmeye karar veren ve tüfek arayan A'ya, evindeki tüfeği veren C'nin hareketine "olmasaydı bu fiil işlenemezdi” şeklindeki bakış açısıyla ortaya konulan yaklaşıma, “C'nin tüfeği olmasaydl, D'nin tüfeğiyle de bu fiil işlenebilirdi” şeklinde yanıt ileri sürülebilir ki bu da eski klasik nedensellik anlayışına geri dönüş anlamına gelir. Şu halde önemli olan, sağlanan aracın herhangi bir şekilde suçun işlenmesinde kullanılmış olması değil, kullanılmış olmasa bile, failin işlediği fiil bakımından manevi anlamda da olsa bir etkisinin bulunmasıdır ${ }^{13}$. Elbette manevi etki, maddi anlamda yardım etme kapsamında değil, manevi anlamda suç işleme kararının kuvvetlendirilmesi ya da suça teşvik kapsamında telakki edilebilecektir. Zira faile silah temin edilmesinin, maddi anlamda yardım etme olarak değerlendirilebilmesi, ancak bu silahın fiilin işlenmesinde kullanılmasına bağlıdır. Bu bakımdan manevi etkiye, incelemenin ilerleyen kısımlarında değinilecektir.

9 Özgenç, s. 553; Koca/Üzülmez, s. 487; Artuk/Gökcen/Yenidünya, s. 666; Artuk/Gökcen/Alşahin/Çakır, s. 677; Yıldız, s. 122; Hakeri, s. 590; Zafer, s. 478; Soyaslan, s. 483; Yaşar/Gökcan/Artuç, C. I, s. 1155; Mahmutoğlu/Karadeniz, s. 919.

10 Nitekim araç temininin, failde suç işleme kararına neden olması durumunda artık yardım etmeden değil, azmettirmeden söz edilecektir. Bkz. Halid Özkan, Ceza Hukukunda Azmettirme, Adalet, Ankara 2013, s. 250. Bu tür durumlarda bir kimsenin hem azmettiren hem de manevi anlamda yardım eden olduğu hiçbir şekilde ifade edilemez (Joachim Hruschka, "Alternativfeststellung zwischen Anstiftung und sog. psychischer Beihilfe", JR 1983, s. 179).

11 Roxin, FS-Miyazawa, s. 505; Geppert, s. 267; Evik, s. 217; Artuk/Gökcen/Yenidünya, s. 667; Artuk/ Gökcen/Alşahin/Çakır, s. 678; Özbek/Doğan/Bacaksız/Tepe, s. 525; Zafer, s. 479; Yaşar/Gökcan/Artuç, C. I, s. 1158; Berrin Akbulut, Ceza Hukuku Genel Hükümler, 4. Bası, Adalet, Ankara 2017, s. 665.

12 Jürgen Baumann, "Täterschaft und Teilnahme", JuS 1963, s. 136.

13 Roxin, FS-Miyazawa, s. 501; Akbulut, s. 664. Bu bakımdan doktrinde, aracın mutlaka suçu işlemeye elverişli olması gerektiği yönündeki görüşlerin ne denli yerinde olduğu kuşkuludur. Bu tür görüşler için bkz. Hakeri, s. 590; Zafer, s. 479; Yaşar/Gökcan/Artuç, C. I, s. 1158. Esasında araçların elverişliliği şartı, yardım etme için değil de fiilin işlenmesine araç sağlama şeklindeki yardım etme açısından geçerli olabilir. 
Kanun koyucu, bazı suç tipleri bakımından ilgili suç tipleriyle bağlantılı olarak araçların să̆lanmasını bağımsız suç tipleri olarak ihdas etmiş olsa da ${ }^{14}$ bu durum, genel hükümler kapsamında işlenen suça araç tedarik edilmesinin yardım etme kapsamına dahil edilmesine engel teşkil etmeyecektir. Buna göre "Para ve Kiymetli Damgaları Yapmaya Yarayan Araçlar” başlıklı TCK md. 200 kapsamında paralarla klymetli damgaların üretiminde kullanılan alet veya malzemeyi izinsiz olarak üreten, ülkeye sokan, satan, devreden, satın alan, kabul eden veya muhafaza eden kişilerin bu suçun faili olarak sorumlu tutulacağının belirtilmiş olması karşısında bir bodrum katında arkadaşının temin ettiği matbaa ve yurt dışından getirttiği özel kağıtlarla sahte para basan kişinin yakalanması üzerine hakkında TCK md. 197 hükmüne binaen "Parada Sahtecilik" suçunun faili olarak sorumluluk yoluna gidilecekken matbaa ve kağıdı temin eden kişi, hem parada sahtecilik suçuna yardım eden olarak, hem de TCK md. 200 hükmünde düzenlenen "Para ve Kıymetli Damgaları Yapmaya Yarayan Araçlar" suçunun faili olarak sorumlu tutulur. Ancak kişinin failliğin şerikliğe asliliği kuralı gereğince sadece "Para ve Kıymetli Damgaları Yapmaya Yarayan Araçlar" suçuna faillikten dolayı sorumlu tutulması yoluna gidilecektir.

Benzer şekilde "Uyuşturucu veya Uyarıcı Madde Kullanılmasını Kolaylaştırma" başlıklı TCK md. 190 hükmüne göre uyuşturucu veya uyarıcı madde kullanılmasını kolaylaştırmak için özel yer, donanım veya malzeme sağlayan kişilerin söz konusu suçun faili olarak cezalandırılacağının belirtilmiş olması karşısında uyuşturucu madde kullanılmasını kolaylaştırmak için özel yer sağlayan bir kimsenin, sağladığ1 yerde uyuşturucu veya uyarıcı madde imal ve ticaretinin yapılması halinde, hem TCK md. 188'de düzenlenen "Uyuşturucu veya Uyarıcı Madde İmal ve Ticareti" suçu bakımından yardım eden olarak, hem de TCK md. 190'da düzenlenen "Uyuşturucu veya Uyarıcı Madde Kullanılmasını Kolaylaştırma” suçu açısından fail olarak sorumluluğu gündeme gelecektir. Ancak işlediği tek fiille bir suçun faili, bir başka suçun ise şeriki konumuna gelen kimsenin ceza sorumluluğu, "failliğin şerikliğe asliliği kuralı” gereğince yalnızca faili olduğu suça göre belirlenecektir.

Bu noktada üzerinde özellikle durulması gereken hususlardan biri, katkının kendisi maddi olmasına ră̆men etkisinin manevi olduğu durumlarda artık maddi anlamda yardımdan değil, manevi anlamda yardımdan söz edilecek olmasıdır. Zira faile fỉilin işlenmesi için temin edilen bir silahın, suçun işlenmesinde kullanılmaması

14 Koca/Üzülmez, s. 487; Devrim Aydın, Türk Ceza Hukukunda Suça İștirak, Yetkin Yayınları, Ankara 2009, s. 179, 180; Hakeri, s. 589; Akbulut, s. 664. 
ve fakat failin suç işleme kararının sağlanan bu silahla kuvvetlendirilmesi durumunda, artık araç sağlama hareketinin maddi bir etkisinden söz edilemeyecek, ancak manevi etkisinden bahsedilebilecektir. Bu durumda da aracın faile teslim edilmesi, suçun işlenmesinde kullanılan araçların sağlanması suretiyle maddi yardım etme olarak değil, suç işleme kararının kuvvetlendirilmesinden bahisle manevi yardım etme kapsamında değerlendirilebilecektir. Nitekim burada suçun işlenmesinde "kullanılan" araçların sağlanmasından söz edilmektedir ${ }^{15}$. İşte bu durum, maddi nitelik arz eden katkının, mutlaka maddi anlamda yardım etme olarak kabul edilmesi gerektiği anlamına gelmeyeceğini açıkça göstermektedir ${ }^{16}$. Böylelikle fiilin işlenmesinde kullanılmak üzere faile araç sağlandığında yardım etmeden söz edilebilmesi için söz konusu araçların mutlaka suçun işlenmesinde kullanılmış olmasının şart olmadığı da ifade edilebilir ${ }^{17}$.

Failin suç işleme kararının icraya dönüşmesini mümkün kılacak, suçun işlenmesi bakımından elverişli olan her türlü taşınır yahut da taşınmaz vasıtanın faile temin edilmesi araç sağlama anlamına gelecektir"18. Bununla birlikte “...iş ve vasıtanın temini..." şeklindeki ifadenin yer aldığ 765 sayılı TCK' da, kapsamın geniş tutulması maksadıyla "iş" şeklindeki ifadeye de yer verildiğinden dolayı faile bir takım hizmetler sağlanması da bu kapsamda addedilmiştir ${ }^{19}$. Ancak faile suçun işlenmesini kolaylaştıracak veya mümkün kılacak şekilde vasıta sağlanması dışında bir iş temin edilmesi veya bir hizmet sunulması, zaten suçun işlenmesinden önce veya işlenmesi esnasında yardımda bulunarak icrasını kolaylaştırma kapsamında kabul edilebileceğinden söz konusu ifadenin gereksiz olduğu sonucuna ulaşılmış olmalı $\mathrm{ki}^{20} 5237$ sayılı TCK' da "iş temini”" ifadesine haklı olarak yer verilmemiştir.

15 Evik, s. 217; Mahmutoğlu/Karadeniz, s. 922; Artuk/Gökcen/Alşahin/Çakır, s. 678.

16 Claus Roxin, Strafrecht Allgemeiner Teil, Band II, C.H. Beck, München 2003, § 26 kn. 197.

17 Özgenç, s. 553; Artuk/Gökcen/Alşahin/Çakır, s. 678; Aydın, s. 180; Mahmutoğlu/Karadeniz, s. 923; Akbulut, s. 665.

18 Sulhi Dönmezer/Sahir Erman: Nazari ve Tatbiki Ceza Hukuku, Beta Yayınları, C. II, 10. Bası, İstanbul 1997, s. 530; Recep Gülşen, "Bir Fer'i Maddi İştirak Şekli Olarak İş veya Vasıta Tedariki (TCK m. 65/II)", Prof. Dr. Çetin Özek Armağanı, GÜ Yay., İstanbul 2004, s. 432; Aydın, s. 179; Mahmutoğlu/Karadeniz, S. 923.

19 Ayhan Önder, Ceza Hukuku Genel Hükümler, Filiz Kitabevi, C. II-III, 2. Bası, İstanbul, 1992s. 468; Dönmezer/Erman, C. II, s. 530.

20 Nitekim Dönmezer/Erman, her türlü hizmetin iş tedariki kapsamına dahil edilmesi durumunda fer'i maddi iştirakin, yani yardım etmenin araç sağlama dışındaki ikinci hali olan fiilin işlenmesini kolaylaştırmayla iş tedariki arasındaki farkın ortadan kalkacağına vurgu yapmıştır (Dönmezer/Erman, C.II, s. 530). Dönmezer/ Erman, sanki bu iki durum arasında bir fark varmış gibi ifade kullanmış olsa da kanaatimize göre işlenen yahut da işlenecek olan bir suçun işlenmesini kolaylaştıracak şekilde hizmet sunulmasının, kanunda ayrıca "hizmet veya iş tedarik edilmesi" şeklinde bir ifadeye yer verilmesini gereksiz kılacak şekilde "fiilin icrasını kolaylaştırma" kapsamında yer alabilecek nitelikte olduğu rahatlıkla belirtilebilir. 
Tam da bu kapsamda faile suçun işlenmesini mümkün kulacak şekilde araç temin edilmesinin de "fiilin icrasınt kolaylaştırma" kapsamında telakki edilebileceği, bu minvalde kanunda ayrıca "araç sağlanması" unsuruna gerek olmayabileceği şeklinde bir görüş̧ de ileri sürülebilir. Nitekim suçun işlenmesinde kullanılacak olan araçların faile sağlanması, rahatlıkla suçun işlenmesinden önce veya işlenmesi esnasında fiilin icrasını kolaylaştırma kapsamında anlaşılabilir. Zaten araç sağlanması dışındaki tüm maddi nitelik taşıyan yardımların cezasız kalmaması adına bu şekilde tüm maddi nitelik arz eden yardımları kapsamında bulunduran bir ifadeye yer verildiğine dikkat çekilmektedir ${ }^{21}$. Bu da göstermektedir ki, araç sağlamaya ayrıca yer verilmeksizin sadece fiilin icrasının kolaylaştırılmasının belirtilmesiyle yetinilebilirdi.

Buna rağmen her ne kadar Türk doktrininde bir görüş tarafından araç temini ile fiilin icrasını kolaylaştırma mutlak şekilde farklı addedilmiş ve aralarındaki sınır, araçların sağlandığı zamana göre belirlenmiş ve vasıtanın fiilin işlenmesinden evvel sağlanması durumunda "araç sağlanması"ndan, vasıtanın fiilin işlenmesi esnasında tedarik edilmesi halinde ise "fiilin icrasının kolaylaştırılması"ndan söz edilebileceği ileri sürülmüş̧ ${ }^{22}$ olsa da, kanaatimize göre bu tür bir ayrım, oldukça suni ve göreceli olduğundan yerinde değildir ${ }^{23}$. Kanun koyucunun, gerek 765 sayılı TCK döneminde gerekse 5237 sayılı TCK döneminde bu şekilde faile suçun işlenmesinde kullanılan araçların tedarik edilmesini ayrıca vurgulamasının pratikte pek bir öneminin olmadığının altı çizilmelidir. Zira suç işleyeceği bilinen bir kimseye araç sağlanması, bu araçların kullanılması halinde zaten fiilin icrasını kolaylaştırma olacakken suçun işlenmesinde kullanılmamış olan bir aracın faile temin edilmiş olması halinde iki ihtimalden biri gündeme gelecektir.

Araçların temininin, failde suç işleme kararının kuvvetlenmesi şeklinde bile olsa en ufak bir etkisinin olmaması halinde, aracı temin eden kişi bakımından gerek Türk hukukunda gerekse Alman hukukunda cezalandırılmayan akim kalmış yardım

21 Evik, s. 220.

22 Dönmezer/Erman, C. II, s. 530; Aydın, s. 179.

23 Koca/Üzülmez, s. 488; Artuk/Gökcen/Alşahin/Çakır, s. 679. Nitekim Önder, bu görüşe karşı olarak suçun icrasını kolaylaştıran her türlü eylemin bu kapsamda değerlendirilebileceğini, bu nedenle bu tür hareketlerin suçun işlenmesinden evvel gerçekleştirilmiş olmasının şart olmadığını, suç işlenirken de suçun icrasının kolaylaştırılmasından söz edilebileceğini vurgulamıştır (Önder, C.II, s. 468). Bu yönde bir tartışmanın olduğuna dair bkz. Artuk/Gökcen/Alşahin/Çakır, s. 679; Akbulut, s. 665. 
etmenin mevzu bahis olacağı yönündeki ilk ihtimal ${ }^{24}$ bir tarafa bırakılıp ikinci ihtimal ele alındığında, failin kendisine sağlanan aracı fiilin işlenmesinde kullanmamasına rağmen söz konusu araçların fiili işleme konusundaki kararını artırması, kuvvetlendirmesi durumunda daha evvel değinildiği üzere kanundaki unsurlardan "suç işleme kararını kuvvetlendirme"nin gündeme gelebileceği, bu kapsamda da manevi yardım etmenin söz konusu olabileceği belirtilebilir ${ }^{25}$. Buna göre bir kimsenin evine girmeye karar veren faile kapıyı açabilmesi için anahtar sağlanması ve fakat failin evin önüne gittiğinde kapının açık unutulması nedeniyle anahtara ihtiyacının kalmaması yahut da failin anahtarı kullanmayarak kapıyı kırması durumunda manevi yardım etmeden bahsedilebilecektir ${ }^{26}$. Dolayısıyla sağlanan araçların fiilin işlenmesinde kullanılması ve fiilin işlenmesinin bu araçla mümkün kılınması yahut da kolaylaştırılması durumunda araç temin eden kişi, TCK md. 39 kapsamında yer verilen "suçun işlenmesinden önce veya işlenmesi sırasında yardımda bulunarak icrasını kolaylaştırma" unsurundan bahisle yardım eden olarak sorumlu tutulabilecekken araçların fiilin işlenmesinde hiçbir şekilde kullanılmamış olması durumunda ise söz konusu araçların failin fiili işlemesi bakımından "en ufak bir etkisinin olması halinde" bu defa "suç işleme kararını kuvvetlendirme" unsurundan bahisle yardım eden olarak sorumlu tutulabilecektir ${ }^{27}$. Şu halde "iş temini" unsurunun

24 Baumann, s. 136; Dönmezer/Erman, C. II, s. 530; Koca/Üzülmez, s. 488; Artuk/Gökcen/ Yenidünya, s. 667; Centel/Zafer/Çakmut, s. 501.

25 Hans-Heinrich Jescheck/Thomas Weigend, Lehrbuch des Strafrechts, Allgemeiner Teil, 5. Auflage, Duncker\&Humblot, Berlin 1996 § 64 III 2 a; Harro Otto, "Anstiftung und Beihilfe", JuS 1982, s. 564; Aydın, s. 180; Evik, s. 218; Yaşar/Gökcan/Artuç, C. I, s. 1158. Failin fiili işleme kararının kuvvetlendirilmesi yoluyla da manevi yardım etmenin cezasızlığı için bzk. Hruschka, JR 1983, s. 178. Yargıtay 1. Ceza Dairesi, 11.04.2011 tarih ve 319/2167 sayılı kararında, olay sırasında iki farklı tabancadan ateşlendiği ekspertiz raporuyla anlaşılan toplam 16 adet $(9+7)$ mermi kovanının elde edildiği, sanık Yücel'in silahla ateşine, mağdur-katılan Taner tarafından da aynı şekilde karşılık verildiği, böylece sanıklar Mürsel ve Yüksel'in mağdurlara tabancayla ateş ettiklerinin maddi delillerle ve tanık anlatımlarıyla tereddütsüz belirlenemediği, bu nedenle eylemlerinin diğer sanık Yücel'in yanında yer almak suretiyle suçun işlenmesini kolaylaştırmak olduğunun anlaşılması karşısında, haklarında TCK'nın 39. maddesinin uygulanması yerine, TCK'nın 37. maddesi uygulanmak suretiyle fazla ceza tayinini hukuka aykırı bulmuştur. Karar için bkz. Artuk/Gökcen/Yenidünya, s. 667, dpn. 326; Artuk/Gökcen/Alşahin/Çakır, s. 678, dpn. 326.

26 RGSt 58, 113 (Jescheck/Weigend, § 64 III 2 a); BGHSt 2, 129 (Baumann/Weber/Mitch/Eisele, § 26 kn. 103).

27 Bununla birlikte kanunda yer alan "fiilin işlenmesinde kullanılan" araçların sağlanması şeklindeki ifade, yardım etme için araç temininin mutlaka fiilin işlenmesinden evvel sağlanması gerektiği, aksi takdirde, fiilin işlenmesi esnasında sağlanan araçların kişiyi müşterek fail haline getireceği yönündeki argümana (Centel/Zafer/Çakmut, s. 501) bir gerekçe oluşturmayacak, yalnızca faile sağlanan aracın fiilin işlenmesinde kullanılmaması durumunda "araç sağlama" şeklindeki maddi yardım etmeden bahisle kişinin sorumlu tutulmasının önüne geçilmesini sağlayacaktır. Elbette belirtildiği üzere kişinin sağladığı araç, suçun işlenmesinde kullanılmış olmasa dahi failin fiili işleme kararını kuvvetlendirmiş olabilir ki bu defa da manevi yardım etmeden sorumluluk söz konusu olabilir. 
yanı sıra "araç temini" de diğer unsurların içerisinde eritilebilecek durumda olduğundan mevcut kanuni düzenlemede olmasa da sorun teşkil etmeyecek unsurlardan biridir ${ }^{28}$.

Zaten bu argümanımızın ne denli haklı olduğunu, Alman doktrininde araç sağlama ile fiilin icrasını kolaylaştırmanın birbirinden ayrı değerlendirilmemiş olması, her ikisinin de bir bütün halinde maddi anlamda yardım kapsamında telakki edilmiş olması açıkça ortaya koymaktadır. Değinildiği üzere Alman Ceza Kanunu'nda TCK'da olduğu gibi yardım etme hareketlerinden ne anlaşılması gerektiği belirtilmemiş, bu husus doktrine bırakılmıştır. Bu anlamda Alman hukuk doktrininde, "araç sağlama" değil de, araç sağlamayı da kapsamına alacak şekilde "fiilin icrasını kolaylaştırma" ön plana çıkmaktadır.

\section{b. Fiilin İcrasını Kolaylaştırma}

Maddi anlamda yardım etme, failin işlediği fiilin üzerinde hakimiyeti bulunmayan kişinin bu hareketi azmettirme olmamak kaydıla hukuka aykırı fiili ile bir başka kişinin fiilinin “dışardan görülebilecek” şekilde desteklediği her durumda söz konusu olabilir ${ }^{29}$. Buna göre bir kimseyi öldürme düşüncesinde olan bir kişiye, öldürme fiilini işlemesi için tabanca verilmesinin yanı sıra failin öldürülecek kişinin bulunduğu güzergaha otomobille götürülmesi ya da araçta beklenip suç işlendikten sonra failin taşınmas $1^{30}$, hırsızlık yapılırken el feneri tutulması, merdivenin olay yerine getirilmesi ve duvara dayanmasi ${ }^{31}$, fiilin işlendiği esnada apartmanın kapısında gözcü olarak beklenmesi yahut da suç işleme arzusunda olduğu bilinen

28 Türk doktrininde suçun icrasını kolaylaştırmadan söz edilirken fiile veya faile yönelik araç temin etme dışındaki kişisel hizmetlere işaret edilmiş, araç sağlama ile fiilin icrasını kolaylaştırma arasında yapay bir farklılık oluşturulmaya çalışılmıştır. Bkz. Evik, s. 220; Zafer, s. 480.

29 Volker Krey/Robert Esser, Deutsches Strafrecht, Allgemeiner Teil, 5. Auflage, Stuttgart 2012, § $32 \mathrm{kn}$. 1071; Kristian Kühl, Strafrecht Allgemeiner Teil, 7. Auflage, Vahlen, München 2012, § 20 kn. 223; Bernd Schünemann, "Täterschaft und Teilnahme”, Leipziger Kommentar Strafgesetzbuch, Band 1, §§ 1-51 StGB, 12. Auflage, De Gruyter, 2010, § 27 kn. 48; Uwe Murmann, Grundkurs Strafrecht, 3. Auflage, C.H. Beck, München 2015, $\$ 27$ kn. 129; Baunack, s. 99; Rudolf Rengier, Strafrecht Allgemeiner Teil, 7. Auflage, C.H. Beck, München 2015, 45/85; Wolfgang Joecks, "Täterschaft und Teilnahme", Münchener Kommentar zum Strafgesetzbuch, Band 1, §§ 1-51 StGB, Verlag C.H. Beck, München 2003, § 27 kn. 5; Koca/Üzülmez, s. 488.

30 “İnceleme dışı sanık Hakan'ın kimliği belirlenemeyen diğer şahıs ile birlikte maktulü bıçaklamak suretiyle öldürdükleri olayda, suçun işlenmesinden önce maktulün iş yerinde bulunduğunu bildiren ve suçun işlenmesi sırasında da kasten öldürme suçunun azmettiricisi olan sanık Yakup ile birlikte olay yerini görmeyen bir noktada araç içerisinde bekleyip eylemden sonra olay yerinden kaçmaya yardımda bulunan sanık Hasan'ın suça iştiraki, 5237 sayılı TCK'nın 39/2-c maddesi kapsamında suçun işlenmesinden önce maddi yardımda bulunarak icrasını kolaylaştırmak, eylem sonrasında da olay yerinden kaçışa yardım etme suretiyle yardım eden niteliğindedir." - YCGK, 03.06.2014, 109-305 - Akbulut, s. 665, dpn. 2023.

31 Haft, s. 222; Artuk/Gökcen/Yenidünya, s. 671; Artuk/Gökcen/Alşahin/Çakır, s. 682. 
kişilerin birbiriyle tanıştırılmasi ${ }^{32}$ şeklindeki hareketler de maddi anlamda yardım etme olarak kabul edilebilecektir ${ }^{33}$. Zira failin fiili üzerinde etki eden bu katk1larla birlikte fiilin işlenmesi için gerekli koşullar oluşturulmakta veya fiilin işlenmesi bir şekilde kolaylaştırılmaktadır. Nitekim gözcülükte de, fiilin işlenmesi esnasında söz konusu olabilecek muhtemel saldırılara karşı uyarı veya koruma fonksiyonunun üstlenilmesi söz konusudur ${ }^{34}$.

\section{Tam bu noktada gözcülük, üzerinde özel olarak durulması gereken bir husus}

olarak karşımıza çıkmaktadır. Bir defa daha en baştan gözcülük yaparak fiilin işlenmesine katkı sağlayan bir kimse, fail yahut da failin fiili üzerinde iştirakin üç derecesinden biri kapsamında etki edebilir ve buna göre de bu katkı, kişinin sorumluluğunu beraberinde getirebilir. Bu derecelerden ilki müşterek faillik olup bu etki, en üst katta yer alırken bir alt katta maddi anlamda yardım etme, en alt katta ise manevi anlamda yardım etme bulunmaktadır. Esasında maddi anlamda yardımla manevi anlamda yardım arasında kademeli bir ilişki bulunmamaktadır. Dolayısıyla buradaki sıralamamızın, manevi yardım karşısında maddi anlamda yardımın görülebilen, ispatı daha kolay, etkisi daha belirgin bir yardım olmasından kaynaklandığının altı çizilmelidir.

İncelemeye orta katta yer alan maddi anlamda yardım etme olarak nitelendirilen gözcülükten başlanması daha doğru olacaktır. Zira failin fiili işlediği esnada, gözcü olarak bekleyerek fiilin işlenmesine katkı sağlayan kişinin bu katkısı, kural olarak fiilin icrasını kolaylaştırıcı bir etki gösterir ki, bu da maddi anlamda yardım etme olarak nitelendirilir. Buna göre failin fiili işlediği anda kapıda gözcü olarak bekleyen kişinin, fiilin işlendiği yere doğru gelmekte olan kişilerin güzergahlarında çeşitli

32 Nitekim Yargıtay 10. Ceza Dairesi, 04.06.2012 tarih ve 2012/1119, 2012/10319 sayılı kararında sanığın, suçun kanuni tanımında yer alan fiili gerçekleştirmediği, ancak uyuşturucu madde almak isteyen şahısları, uyuşturucu satıcısı olan diğer sanıkla tanıştırmak suretiyle, diğer sanığın işlediği suçun icrasını kolaylaştırdığı dikkate alınarak, suçun işlenmesine yardım eden sanık hakkında TCK'nın 39. maddesinin uygulanması gerektiğinin gözetilmediği sonucuna ulaşmıştır (Artuk/Gökcen/Yenidünya, TCK Şerhi, C. 1, 2. Bask1, s. 1330).

33 Geppert, s. 268. Bununla birlikte Türk doktrininde bazı yazarlar, TCK'da yer alan "fiilin işlenmesinde kullanılan araçları sağlamak" ifadesi yer aldığından araç sağlama dışındaki fiilin icrasını kolaylaştıran her türlü maddi yardımın bu kapsamda telakki edildiğine dikkat çekmişlerdir. Bkz. Evik, s. 220; Yaşar/ Gökcan/Artuç, C. I, s. 1158. Kanaatimiz, incelememizde belirttiğimiz üzere araçların kullanılmasının kanunda ayrıca belirtilmesinin ne denli makul olduğu hususunda şüphelerin bulunduğu yönünde olduğundan araç teminin de pekala bu kapsamda kabul edilebileceği yönündedir. Öyle ki doktrinde bu tür bir harekete yer verilmesinin de, araç sağlama dışındaki her türlü maddi yardımın cezasız kalmaması arzusundan kaynaklandığına dikkat çekilmektedir (Evik, s. 220). Şu halde "araç sağlama" unsuruna ayrıca yer verilmeden de bu hareketle yetinilebilir, pekala araç sağlama da bu hareket kapsamına dahil edilebilirdi.

34 Önder, C.II, s. 468; Kühl, § 20 kn. 224; Stephan A. Osnabrügge, Die Beihilfe und ihr Erfolg, Ducker\&Humblot, Berlin 2002, s. 137. 
bahanelerle değişikliklere neden olması ve bu suretle failin fiilini güvence altına alması durumunda maddi katkılardan söz edilecek, bu da maddi yardım etme olarak nitelendirilecektir ${ }^{35}$.

Bununla birlikte yardımda bulunularak fiilin icrasının kolaylaştırıldığından söz edilebilmesi için yapılan bu katkıların fiil üzerinde hakimiyet elde edilmesi sonucunu beraberinde getirmemesi gerekir. Nitekim gözcü olarak beklemek gibi fiilin işlenmesinin kolaylaştırılması, başta fiilin ortak işlenmesine yönelik karşılıklı bir anlaşmanın bulunması olmak üzere koşullarının gerçekleşmesi halinde bir üst basamakta yer alan müşterek failliğe de bir temel teşkil edebilir ${ }^{36}$. Bu anlamda Yargitay tarafından verilen bir karara da dayanarak gözcülüğün fiilin icrasını kolaylaştırma, dolayısıyla da yardım etme olacağı görüşünü belirten Önder ’in bu şekilde doğrudan bir sonuca ulaşması doğru değildir ${ }^{37}$. Benzer şekilde her ne kadar bazı kararlarında somut olayın koşulları üzerinde bütüncül bir değerlendirme yapıp isabetli kararlar verse de ${ }^{38}$, Yargıtay’ın da son dönem verdiği bazı kararlarda doğrudan bir sonuca ulaşarak gözcülüğü müşterek faillik olarak nitelendirmesi yerinde değildir $^{39}$. Elbette burada müşterek faillikle yardım etme arasındaki ayrımın belirlenmesinde, ortaya konulan katkının suçun işlenmesi açısından önemi ve ağırlığı önemli bir belirti olacaktır ${ }^{40}$.

Keza bu tür katkıları sağlayan kişilerin müşterek fail olarak mı yoksa yardım eden olarak mı sorumlu tutulacaklarına ilişkin olarak yapılacak irdeleme bakımından fiile yapılan söz konusu katkıların ne zaman sağlanmış olduğunun tek başına bir önemi olmadığını da ifade etmek gerekir. Yani yalnızca bu katkıların failin fiili işlemesinden önce mi, yoksa fiili işlediği esnada mı gerçekleştirildiğinden hareketle, katkıyı

35 Hilgendorf/Valerius, $\S 9 \mathrm{kn} .147$.

36 Kühl, § 20 kn. 224; Roxin, AT II, § 25 kn. 212; § 26 kn. 214; Krey/Esser, § 32 kn. 1074; Koca/Üzülmez, s. 488; Akbulut, s. 665; Hakeri, s. 571; Osman Yaşar/Hasan Tahsin Gökcan/Mustafa Artuç, YorumluUygulamalı Türk Ceza Kanunu, C. I, 2. Baskı, Adalet, Ankara 2014, s. 1155.

37 Önder, C.II, s. 468.

38 Nitekim Yargıtay 1. Ceza Dairesi, 03.03.2011 tarih ve 2011/400-1222 sayılı kararında aralarında arkadaşlık ilişkisi bulunan sanıklar İ. ve E. ile maktul S.'nin, olay tarihinde olayın meydana geldiği köprü altına giderek birlikte alkol aldıkları, burada sanıklardan E.'nin maktule, M. isimli kızla olan ilişkisini bitirmesini söylediği, maktulün bunu kabul etmediği, bunun üzerine sanık İ.'nin 13 bıçak darbesi ve taşla başına vurmak suretiyle yardım eden olarak suça katıldı̆̆ı olayda, sadece öldürme kastına yönelik çok sayıda bıçak darbesi ve taşla vurmanın canavarca hisle veya eziyet çektirerek öldürme suçuna kanıt sayılamayacağı... yönünde bir karar vermiştir. Karar için bkz. Mahmutoğlu/Karadeniz, s. 926, dpn. 43.

39 Hakeri, s. 571. Örnek karar için bkz. Y. 6. CD., 04.04.2007, 4290. Türk doktrininde de gözcülüğü direkt olarak faillik kapsamında telakki eden görüşler için bkz. Hafızoğulları/Özen, s. 373.

40 Reinhart Maurach/Karl Heinz Gössel/Heinz Zipf/Dieter Dölling/Christian Laue/Joachim Renzikowski, Strafrecht Allgemeiner Teil, Teilband 2, 8. Auflage, C.F.Müller, 2014, § 52 kn. 8; Evik, s. 196. 
sağlayan kişinin fail ya da şerik olacağı yönünde bir sonuca ulaşılması yerinde değildir $^{41}$. Gerçi 765 sayılı TCK döneminde Türk doktrininde yardım etme için iş ve vasıta tedarikinin suç teşkil eden hareketin icrasından evvel gerçekleştirilmiş olması gerektiği, bu tür katkıların suçun icrası ile aynı zamanda olduğunda müşterek failliği beraberinde getirebileceği yönünde bir takım görüşler ileri sürülmüş olsa $\mathrm{da}^{42}$ faillik konusundaki kriter, hiçbir zaman salt vasıta temininin ne zaman yapıldığına bağlı tutulamaz. Ancak elbette ortaya konulan katkının önemi ve ağırlığının belirlenmesinde, vasıtanın sağlandığg zamanın da göz önünde bulundurulacağında herhangi bir tereddüt bulunmamaktadır ${ }^{43}$. Dolayısıyla suçun tamamlanmasına kadar faile sağlanan araçlar da, araçları temin eden kişinin müşterek fail olmaması kaydıyla yardım etmeyi gündeme getirebilecektir.

Bu minvalde hakim, somut olayın koşullarını dikkate almak suretiyle katkıların önemini değerlendirip ilk olarak müşterek failliğin koşullarının oluşup oluşmadığını irdeleyecek, failliğe ilişkin şartların gerçekleşmemesi halinde, yani fiilin işlenişi üzerinde hakimiyetin bulunduğunun tespit edilememesi halinde bu defa yardım etme üzerinden bir inceleme yapacaktır ${ }^{44}$. Bu değerlendirme, fiilin işlenmesi için verilen

41 Suçun işlenmesi sırasında da pekala yapılan yardım, kişinin yardım eden olarak sorumlu tutulması sonucunu beraberinde getirebilir. Bkz. Yaşar/Gökcan/Artuç, C. I, s. 1158; Akbulut, s. 665.

42 Dönmezer/Erman, C. II, s. 530, 531.

43 Yaşar/Gökcan/Artuç, C. I, s. 1158. Nitekim Dönmezer/Erman da iki iştirak şekli arasındaki sınırın, katkının sağlandığı ana göre belirlenmesinin tam manasıyla bir ölçüt olamayacağına dikkat çekmiş ve yapılan katkıların somut olaydaki öneminin hakim tarafından takdir edilmesi gerektiğine vurgu yapmıştır (Dönmezer/Erman, C. II, s. 531).

44 Aydın, s. 177; Evik, s. 196. Nitekim Yargitay 6. Ceza Dairesi'nin 22.01.2007 tarih ve 19090/134 say1lı kararında pencereye tırmanan diğer sanığı yukarı kaldırarak yardım edip gözcülük yapmak suretiyle eyleme katılan sanık hakkında 37/1. madde yerine 39/2. maddenin uygulanması kanuna aykırı görülmüştür. Bkz. Yaşar/Gökcan/Artuç, C. I, s. 1159. Bu noktada somut olayın koşullarını dikkate almak suretiyle katkıların önemini değerlendirilip bir sonuca ulaşılması gerektiği yönündeki tespit açısından Yaşar/ Gökcan/Artuç tarafindan verilen şu örnek oldukça açıklayıcı görünmektedir: "Bir dă̆ evinin soyulmasında gözcülük yapan kişinin eylemi, yalnızca kolaylaştırıcı bir işleve sahip iken, şehir merkezindeki bankanın soyulmasında faile telsizle cadde üzerindeki durumdan bilgi veren kişinin eylemi, suçun işlenişi bakımından büyük bir öneme sahip bulunmaktadır.” Bkz. Yaşar/Gökcan/Artuç, C. I, s. 1158, 1159. Benzer şekilde Yargıtay 1. Ceza Dairesi'nin 15.06.2006 tarihli kararı da somut olayın bütün koşulları dikkate alınarak bir sonuca ulaşılması açısından önemli bir örnek teşkil etmektedir: "Yerel mahkemenin tüm dosya ve deliller kapsamından edindiği kanaate göre, başından beri maktulü etkisiz hale getirerek üzerindeki anahtarı alıp o şekilde hırsızlık yapma konusunda diğer sanıklarla anlaşan, olay gecesi de tamamen diğer sanıklarla birlikte hareket eden, diğer sanıkların maktule yönelik eylemleri sırasında yanlarında bulunan, kendinden geçen maktulün bagajına yüklenmesine yardımcr olan, otomobili kullanan, öldüğü düşünülen maktulün ırmağa atılması eylemine bizzat katılan, ardından yapılan hırsızlık eyleminde etkin rol oynayan ve çalınan paralarl diğerleri ile paylaşan, böylece öldürme suçunun hareketi ve neticesi üzerinde diğer sanıklarla birlikte hakimiyet kurduğu anlaşılan, sanık Semih'in öldürme suçunun faili olduğunun kabul edilmesinde bir isabetsizlik görülmediğinden, tebliğnamede yer alan sanık Semih hakkında öldürme suçuyla ilgili olarak 5237 sayılı Yasanın 39. maddesinin uygulanması yönündeki görüşe itibar edilmemiştir.” Bkz. M. Emin Artuk/Ahmet Gökcen/A. Caner Yenidünya, TCK Şerhi, C. 2, 1. Bası, md. 39. 
kararın icra ediliş biçimi, olay öncesinde, esnasında ve sonrasında gerçekleştirilen davranışların birlikte dikkate alınması suretiyle yapılır ${ }^{45}$.

$\mathrm{Bu}$ hususa ilişkin olarak 765 sayılı TCK'da söz konusu katkılar ortaya konulmaksızın failin fiili işlemesinin mümkün olmadığının, bu minvalde yapılan katkıların zorunlu olduğunun tespit edilmesi halinde artık yardım etmeden söz edilemeyeceğini, yani failliğin gündeme geleceğini içeren düzenleme de (md. 65) bu açıdan değerlendirilmekteydi ${ }^{46}$. Bununla birlikte mevcut ceza kanununda bu şekilde bir düzenlemeye yer verilmemiş olması, fiil hakimiyeti prensibinin benimsenmesiyle bu düzenlemeye gerek kalmamış olmasından kaynaklanmaktadır. Bu da, Türk doktrininde söz konusu düzenlemenin yürürlükten kaldırılmasına ve "fiil hakimiyeti" prensibine yöneltilen eleştirilerin ${ }^{47}$ ne denli yersiz olduğunu göstermektedir. Diğer bir ifadeyle bu kriterle birlikte faillik-şeriklik ayrımı konusunda hangi teorinin benimsendiği belli olmayan 765 say1l TCK'da mevcut olan bu tarz bir düzenleme (md. 65) tamamen gereksiz hale gelmiştir ${ }^{48}$. Nitekim bu şekilde bir düzenleme ihdas edilmemiş olsa bile, işlenen fiile kasıtlı olarak katkıda bulunan bir kimsenin katkısının fiilin işlenişi üzerinde hakimiyet sağlaması sonucunu da beraberinde getirecek derece önem arz etmesi durumunda artık yardım etmeden değil, müşterek faillikten söz edilecektir"49. Bu husus, TCK md. 37'nin gerekçesinde yer alan “...gözcülük yapma fiilinin diğer kişilerle birlikte işlenen yağma suçunun gerçekleşmesine olan etkisi bir bütün olarak değerlendirildiğinde, gözcülük yapan kişinin de diğer suç ortaklarlyla birlikte suçun işlenişi üzerinde ortak hakimiyet kurduğu sonucuna ulaşıllır. Bu durumda ise gözcülük yapan kişinin de fail olarak sorumlu tutulması gerekir." şeklindeki ifadelerden de anlaşılmaktadır. Bu bakımdan suç işlenirken gözcülük yapılması şeklindeki katkının müşterek failliği beraberinde getirebilmesi için bu gözcülüğün, failin fiili neticeye başarıyla ulaşacak şekilde gerçekleştirmesi açısından

45 Evik, s. 200.

46 Dönmezer/Erman, C. II, s. 531.

47 Hafizoğulları/Özen, zorunlu yardım etmenin öngörülmediği 5237 sayılı TCK'nın iştirak kurumunu kısırlaştırdığını, yenilik denen şeyin “suçun işlenişi üzerinde ortak hakimiyet olduğu”nu, bunun hiçbir maddede yer almadığını ifade etmişlerdir (Hafızoğulları/Özen, s. 372). Önemle belirtmek gerekir ki, iştirak kurumlarının birbiriyle iç içe geçmesinin önüne geçilmesi, kısırlaştırma değil, bir kurumun belirli bir kriterle belirli hale getirilmesidir. Bu konuda gerekli açıklamalar için bkz. Özgenç, s. 555.

48 Özgenç, s. 555.

49 Artuk/Gökcen/Alşahin/Çakır, s. 677. 
önemli bir nitelik arz etmesi gerektiğinde herhangi bir tereddüt yoktur ${ }^{50}$. Dikkat edilmelidir ki burada fiilin işlenmesi bakımından katkının zorunluluğundan söz edilmemekte, yalnızca fiilin işlenmesinde önemine vurgu yapılmaktadır. Yoksa zaten fiilin işlenmesi açısından zorunlu olduğu bilinen bir katkıyı sağlayan kişinin, yardım eden olarak değil de müşterek fail olarak sorumlu tutulacağında şüphe bulunmamaktadir ${ }^{51}$.

Nihayet en alt derecede manevi anlamda yardım etme yer alacaktır ki, bu da gözcülüğün müşterek faillik niteliğinde olmaması ve maddi bir niteliği haiz olmaksızın sadece failin fiili işlerken kendisini güvende hissetmesine neden olacak derecede olması durumunda gündeme gelir. Buna göre failin fiili işlemesi esnasında olay yerine birilerinin gelmemesi durumunda, yani expost bir yaklaşım sergilendiğinde gözcü olmasaydı da failin fiili rahatlıkla işleyebileceğinin anlaşılması halinde, gözcünün katkısının maddi nitelikte olmadığg, sadece failin gözcü sayesinde kendisini güvende hissettiği ve fiili daha rahat bir şekilde işlediği yönündeki tespitlerle birlikte failin suç işleme kararının kuvvetlendirildiği ve bu suretle gözcülüğün artık yalnızca manevi bir nitelik arz ettiği ifade edilebilecektir ${ }^{52}$.

Tüm bunların yanında yardımsal katkının mutlaka fail tarafindan işlenen fiil bakımından nedensel olması da gerekir. Bununla birlikte yardım etme niteliğindeki hareketlerin, tipe uygun netice bakımından nedensel olması gerekse de bu, nedenselliğin mutlaka "olmazsa olmaz niteliği haiz olması" gerektiği şeklinde anlaşılmamalıdır. Buna göre yardımsal katkılar, olmazsa olmaz niteliği haiz olmasalar bile failin fiilini kolaylaştıran veya en azından herhangi bir şekilde destekleyen nitelik

50 Krey/Esser, § 32 kn. 1074; Aydın, s. 183; Koca/Üzülmez, s. 448, 449; Zafer, s. 480; Yaşar/Gökcan/Artuç, C. I, s. 1158. Nitekim Yargıtay Ceza Genel Kurulu, 10.05.2011 tarihli 59-85 sayılı kararında sanıkların maktul ile yaşadıkları olay nedeniyle aldıkları suç işleme kararı ve yaptıkları etkin işbölümü çerçevesinde hareket ederek sanıklardan birinin gözcülük yaparak diğerlerinin silahlarla bara girip maktule ateş ederek ölümüne neden oldukları olayda tüm sanıkların suça TCY'nın 37. maddesi anlamında doğrudan fail olarak katıldıklarının kabulünün gerektiği sonucuna ulaşmıştır (İlhan/Erel/Fazla/Halitoğlu ve diğerleri, s. 203 - Aktaran Koca/Üzülmez, s. 449, dpn. 1472).

51 Bu açıdan Türk doktrininde zorunlu katkıların faillik olduğu yönündeki ifadenin yerindeliği şüphesiz ki tartışmaya açık değildir. Burada tartışılması gereken esas husus, zorunlu katkıların failliği beraberinde getirip getirmeyeceği değil, zorunlu olmayan ve fakat fiilin işlenmesi açısından önem arz eden katkıların failliği beraberinde getirip getirmeyeceğidir. Dolayısıyla doktrindeki "katkının zorunluluğu" kriteri üzerinde duran görüşlerin (Hafızoğulları/Özen, s. 374) halen bunu tartışma konusu yapmaları soru işaretlerini içerisinde barındırmaktadır.

Seher, s. 794; Krey/Esser, § 32 kn. 1074. 
de arz edebilir ${ }^{53}$. Nitekim yardım eden konumundaki A'nın, B'ye temin ettiği silahla C'nin öldürülmesi, matkapla firmanın kasasını delmeye çalışan C'ye yemek ve içecek getiren D'nin getirdiklerini yiyip içen C'nin daha hızlı ve canlı bir şekilde çalışmaya başlaması, F'nin E'ye karşı cinsel saldırı suçunu işıediği esnada E'nin çıkardığı seslerden şüphelenen ve evin bahçesine kadar gelen komşuları sıkıntı olmadığını söyleyerek insanları uzaklaştıran bekçi G'nin gözcülük yapması, failin fiilin işleneceği olay yerine bir araçla götürülmesi şeklindeki olayların her birinde maddi yardımda bulunan kişilerin her birinin katkısının maddi anlamda yardım etme olarak değerlendirileceği noktasında herhangi bir soru işareti yoktur ${ }^{54}$.

\subsection{Manevi Anlamda Yardım Etme}

Bir fiilin yardım etme olarak değerlendirilmesi, söz konusu katkının failin fiili üzerindeki etkisinin mutlaka maddi anlamda olmasına bağlı olmayıp bu katkı, failin kararı üzerinde etki göstermesi gibi şekillerle failin manevi durumu üzerinde maddi olmayan nitelikte bir etkiye de sahip olabilir ${ }^{55}$. Bu noktada önem arz eden husus, daha evvel de üzerinde durulduğu üzere katkının manevi nitelikte olması değil, katkının meydana getirdiği etkinin manevi nitelikte olmasıdır. Zira katkının bizatihi kendisi, maddi nitelik taşımasına rağmen fail üzerinde manevi bir etki oluşturmuş da olabilir. Dolayısıyla katkının maddi bir nitelik arz etmesi, bu yardımsal katkının da muhakkak

53 Özgenç, s. 553; Erdem, s. 213; Evik, s. 218. Yazı yazmasını bilmeyen sanığın tehdit mektubunu onun dikte etmesi üzerine yazan kişinin tehdit suçuna suçun icrasını kolaylaştırma suretiyle yardım eden olarak iştirak ettiğinin kabul edildiği Yargıtay kararında (Y. 4. CD. 14.11.1979, E. 1979/6677, K. 1979/6701 Dönmezer/Erman, C. II, s. 531) yardımsal katkıda bulunan kișiye yöneltilen zorlama bir tarafa bırakılıp bizatihi mektubu yazma şeklindeki yardımsal katkısı değerlendirilir ve "olmazsa olmaz" yaklaşımı ile bir irdeleme yapılırsa bu defa "Mektubu bu kişi yazmasaydı da başkası yazardl." yaklaşımı sergilenerek sorumluluktan kurtulması yoluna gidilebilirdi. Ancak yukarıda da ifade edildiği üzere kesinlikle olmazsa olmaz şeklindeki bir nedensellik anlayışı ile inceleme yapılmayacak, failin fiilini en düşük dereceli bir kolaylaştırma dahi yardım etme kapsamında telakki edilecektir (Koca/Üzz̈lmez, s. 487).

54 Bkz. Dönmezer/Erman, C. II, s. 530.

55 Dönmezer/Erman, C. II, s. 531; LK-Schünemann, § 27 kn. 12; Wolfgang Schild, in Nomos Kommentar, Band 1, 4. Auflage, 2013, § 27 kn. 9; Charalambakis, s. 633; Baunack, s. 97; Kristian F. Stoffers, "Streitige Fragen der psychischen Beihilfe im Strafrecht", Jura 1993, s. 11; Bernd Herinrich, Strafrecht Allgemeiner Teil, 4. Auflage, Kohlhammer, Tübingen 2015, kn. 1322; Satzger, s. 515; Kühl, § 20 kn. 223; Seher, s. 795. 
maddi anlamda yardım etme olarak kabul edilmesi gerektiği anlamına gelmeyecektir ${ }^{56}$. $\mathrm{Bu}$ minvalde faile fiili işlemesi için sağlanan bir silahın, hiçbir şekilde fiilin işlenmesinde kullanılmamış olması ve fakat silahın sağlanmasının faildeki fiili işleme kararının kuvvetlenmesine neden olması durumunda maddi nitelikli katkının manevi etkisinden söz edilecek ve temin edilen araç hiç kullanılmamasına rağmen, araç tedarik eden kişi, işlenen fiilden yardım eden olarak sorumlu tutulabilecektir.

Bununla birlikte salt fiilin işlendiği yerde bulunma yahut da planın hazırlanmasına katılma gibi fiillerin de her durumda kişinin manevi yardım eden olarak sorumlu olması sonucunu doğurduğu belirtilemez. Öyle ki bu bakış açısıyla hareket edildiğinde, yardım etmenin cezalandırılabilirlik alanı katlanılmaz derecede genişler ve düşman ceza hukuku anlayışıyla düşüncenin dahi ceza yaptırımı altına alınması gündeme gelir ${ }^{57}$. Bu anlamda manevi anlamda yardım etme, henüz azmettirme hareketinin eşiğine geçmiş olmasa bile yine de izin verilmeyen riski aşacak şekilde yardımsal katkının faile veya failin fiiline yönelik manevi bir etki oluşturması durumunda söz konusu olabilecek ${ }^{58}$, bu bakımdan da manevi anlamda etki oluşturan katkılarla netice arasında nedensel bir bağın bulunmasının hiçbir şekilde aranmayacağ1 yönünde bir sonuca ulaşılmayacaktır ${ }^{59}$. Zira manevi yardım, işlenen fiil bakımından failin ruhsal durumu üzerinde, bu çerçevede fiil ya da fiilin neticesi üzerinde etki $\operatorname{eder}^{60}$. Bu anlamda bu yardım türünde kişinin yaptığ 1 yardımın etkisi, failin fiilinden çok failin kendisine yöneliktir ${ }^{61}$. Fakat bu etkinin maddi yardımda olduğu gibi kolaylıkla tespit edilebilir bir niteliği haiz olmadığı da üzerinde durulması gereken

56 Satzger, s. 515; Bu bağlamda Roxin tarafından manevi yardım etmeden bahsedilirken manevi yardım etme durumlarında kişinin vücutsal katkısından değil, yalnızca fikirsel katkılarından, fiilin işlenişine katılımından söz edileceğine dair açıklamalarını (Roxin, FS-Miyazawa, s. 505; Roxin, AT II, § 26 Kn. 197) yerinde görmediğimizi önemle vurgulamak gerekir. Bu çerçevede manevi yardım etmenin plan üzerinde çalışma gibi maddi yardım söz konusu olmayacak şekilde bir anlam ifade ettiğini belirten Baumann/Weber/Mitsch/Eisele 'nin görüşüne de katılmadığımızı ifade etmek gerekir. Bununla birlikte daha evvel de ifade ettiğimiz üzere sırf bu nedenlerden dolayı, yani maddi nitelikte katkıların aynı zamanda manevi anlamda yardım etme olarak da kabul edilebilir nitelikte olması hasebiyle Renzikowski, yardım etmenin bu iki türü arasındaki ayrımı gereksiz görmüştür (Maurach/Gössel/Zipf, $§ 52$ kn. 7). Ayrıca bu konuya ilişkin detaylı açıklamalar için bkz. Muhammed Demirel, Suça İştirakte Bağlılık Kuralı, Doktora Tezi, İstanbul 2017.

57 Satzger, s. 515.

58 Roxin, AT II, § 26 kn. 198; LK-Schünemann, § 27 kn. 49; Rengier, 45/86; Walter Gropp, Strafrecht Allgemeiner Teil, 4. Auflage, Springer 2015, § 10 kn. 299; Günther Heine/Bettina Weißer, "Täterschaft und Teilnahme", Schönke/Schroeder Strafgesetzbuch Kommentar, 29. Auflage, Verlag C.H. Beck, München 2014, § 27 kn. 15; Farklı ihtimaller dahilinde inceleme için bkz. Charalambakis, s. 634.

59 Schünemann, $\S 27$ kn. 12.

60 Roxin, FS-Miyazawa, s. 501, 505; Kühl, § 20 kn. 225.

61 Seher, s. 795. 
bir husustur ${ }^{62}$. Öyle ki bizatihi kendisinin "renksiz" bir kavram olduğu kabul edilen ${ }^{63}$ yardım etme bakımından yapılan bu yorum karşısında, manevi yardım etme açısından bir takım zorlukların ortaya çıkması oldukça normaldir. Ancak bu zorlukların bütün manevi anlamda yardım etme türleri açısından var olduğu da belirtilemez. Zira faile bir takım ip uçları vermek suretiyle fiilin işlenişini kolaylaştıran veya ilk alanda mümkün kılan teknik tavsiye niteliğindeki yardımsal hareketlerde bu noktada pek bir sorun ortaya çıkmamaktadır ${ }^{64}$. O halde bu zorlukların daha iyi incelenebilmesi için manevi anlamda yardım etme türlerinin ayrı olarak ele alınmasında yarar bulunmaktadır.

$\mathrm{Bu}$ çerçevede Türk hukukunda açık kanuni düzenlemeden kaynaklı olarak suç işlemeye teşvik etme, suç işleme kararını kuvvetlendirme, fiilin işlenmesinden sonra yardımda bulunulacağ 1 yönünde vaatte bulunma ve nihayet suçun nasıl işleneceği hususunda yol gösterme hareketleri manevi yardım etme olarak kabul edilirken ${ }^{65}$ Alman doktrininde teknik anlamda yol gösterme, failin ceza soruşturmasına tabi tutulmasını önlemeye yönelik davranışlar veya failin suç işleme kararının kuvvetlendirilmesi yahut da kararın sabit kılınması şeklindeki hareketler bu kapsamda telakki edilmektedir ${ }^{66}$. Dolayısıyla bu konuya ilişsin olarak Türk hukuku ile Alman hukuku arasında bir mukayese yapıldığında Alman doktrininde suç işlemeye teşvikten söz edilmediği, bunun dışındaki durumların her birinin karşıllı̆̆nın bulunduğ $u$ ifade edilebilir. Buna rağmen incelememizde Türk hukuku merkezde yer aldığından öncelikle suç işlemeye teşvik ele alınacak, yeri geldiğinde Alman hukukunda kabul edilen davranışlar üzerinde durulacaktır.

\section{a. Suç İşlemeye Teşvik Etme}

Suç işlemeye teşvik etme, zaten suç işleme düşüncesi bulunan ve fakat bu konuda henüz tam manasıyla karar vermemiş olan bir kimsenin ${ }^{67}$, kesin olarak karar vermesine

62 Roxin, AT II, § 26 kn. 197; Heinrich, kn. 1322; Kühl, § 20 kn. 226.

63 Joecks, § 27 kn. 5.

64 Roxin, AT II, $\S 26$ kn. 198.

65 Koca/Üzülmez, s. 487; Artuk/Gökcen/Yenidünya, s. 671; Artuk/Gökcen/Alşahin/Çakır, s. 682; Zafer, s. 478; Soyaslan, s. 483; Yaşar/Gökcan/Artuç, C. I, s. 1156; Akbulut, s. 665; Mahmutoğlu/Karadeniz, s. 919.

66 Schünemann, § 27 kn. 49.

67 Erdem, s. 214. "Fiili işlemeye yönelik karar" kavramının, kasta eşdeğer olduğu ve isteme unsuru olarak kullanıldığı ifade edilmiştir. Nitekim kast, objektif tipiklik unsurlarının bilinmesi ve istenmesi olduğundan kastın isteme unsuru da tipik hareketin gerçekleştirilmesine yönelik karar ve bu kararın icraya dökülmesinden ibaret görülmektedir. Buradan hareketle istemenin iki fonksiyon icra ettiği kabul edilir. Detaylı açıklamalar için bkz. Baunack, s. 105. 
yönelik gerçekleştirilen sözlü veya fiili davranışlardır ${ }^{68}$. Kişinin aklında belli bir kimseye yönelik belirli bir suçun işlenmesi yönünde bir düşünce olmasına rağmen bir türlü icraata geçemediği bir durumdan haberdar olan bir başka kimsenin, bu kişiye karşı düşüncelerini kesin bir karara dönüştürücü sözleri ya da davranışları, azmettirme olarak değil, suç işlemeye teşvik kapsamında manevi yardım etme olarak telakki edilecektir ${ }^{69}$.

Bununla birlikte failde fiili işleme konusunda düşük dereceli bir karar bulunmasına rağmen fiili işleme konusunda gerçek anlamda bazı kuşkuların mevcut olması halinde failde fiili işleme yönündeki kararın varlığı noktasında soru işaretleri gündeme gelecek ve bu defa kişinin bu şüphelerini gidermeye çalışan kişi, manevi yardım eden olarak değil, azmettiren olarak nitelendirilecektir ${ }^{70}$. Bu çerçevede failin fiiline yönelik katkının, azmettirme aşamasına geçmeden yardım etmenin sınırları içerisinde kalabilmesi için, "failde daha evvelden fiili işleme yönünde bazı düşük dereceli tereddütler dışında" büyük oranda bir kararın mevcut olması gerekmektedir. Yani failde hasıl olan ilgili fiilin işlenmesi yönündeki karar, şerik tarafından oluşturulmuş olmamalıdır. Aksi takdirde yardım etmeden değil, azmettirmeden söz edilir.

$\mathrm{Bu}$ anlamda kişinin kararsız olması halinde doğrudan azmettiren ya da yardım eden olduğu yönündeki bir tespit yerinde olmayacaktır. $\mathrm{Bu}$ aşamada kişideki kararsızlıkların giderilmesinin azmettirme mi yoksa yardım etme mi olduğu, tamamen bu kişideki kararsızlığın derecesine bağlı olacak, bunun değerlendirmesi de hakim tarafından yapılacaktır. Dolayısıyla da Türk doktrininde suç işleme fikri ve düşüncesi olan ve fakat suçu işleyip işlememe noktasında kararsızlığı bulunan kişinin, suça

68 Artuk/Gökcen/Yenidünya, s. 672; Artuk/Gökcen/Alşahin/Çakır, s. 684; Hakeri, s. 584; Zafer, s. 479; Yaşar/Gökcan/Artuç, C. I, s. 1156; Mahmutoğlu/Karadeniz, s. 931; Akbulut, s. 666; Özkan, s. 252.

69 Dönmezer/Erman, C.II, s. 532; Önder, C.II, s. 469; Erdem, 214; Aydın, s. 185; Evik, s. 202; Koca/Üzülmez, s. 489; Artuk/Gökcen/Yenidünya, s. 672, 673; Artuk/Gökcen/Alşahin/Çakır, s. 684; Centel/Zafer/Çakmut, s. 481; Yaşar/Gökcan/Artuç, C. I, s. 1156; Mahmutoğlu/Karadeniz, s. 931. Bu noktada failin suça yöneltilmesi için söylenen sözler ve davranışlar dikkatlice değerlendirilmelidir. Burada da failin, şerikle karşılaşmadan evvel suçu işlemeye ne derece kararlı olduğuna dair tespitler yapılmalı, şerikin davranışının etkisi belirlenmeye çalışılmalıdır. Yargıtay, bu konuda bilhassa belirsiz durumlarda haklı olarak şeriki azmettiren olarak değil de yardım eden olarak sorumlu tutma eğilimi göstermektedir. O kadar ki Yargıtay 6. Ceza Dairesi'nin 05.06.2007 tarih ve 19077/7271 sayılı kararında faile iş yerindeki kasada para olduğundan söz eden ve kasanın anahtarının yeriyle ilgili bilgi veren ve çalınan bilgisayarın satışını gerçekleştiren kişinin bu davranışları, azmettirme değil, yardım etme olarak kabul edilmiştir. Karar için bkz. Yaşar/Gökcan/Artuç, C. I, s. 1159. Benzer şekilde Yargıtay 1. Ceza Dairesi, silahla kasten yaralama suçunun asli failin olan sanık Ramazan'ın olay esnasında araçtan tüfeği alıp fişekleri doldurduktan sonra, sanık Ahmet'in "vur ulan şunları" şeklinde beyanda bulunması karşısında, sanık Ahmet'in suç işlemeye teşvik suretiyle eyleme iştirak ettiği gözetilmeyerek azmettirmeden hüküm kurulmasını kanuna aykırı bulmuştur (Y. 1. CD., 23.05.2007, 4007 - Hakeri, s. 592). 
yöneltilmesinin direkt olarak yardım etme olacağı yönündeki genel kabul ${ }^{71}$ tam anlamıyla yerinde değildir. Bu minvalde kanaatimize göre suçu işleme yönünde bir fikri bulunan, ancak henüz tam manasıyla karar vermemiş, bununla birlikte fiili işleme hususunda da kararsızlığı ya da tereddütleri bulunsa da bu tereddütlerin oldukça düşük dereceli olduğu bir durumda, kişinin tam anlamıyla karar vermesinin sağlanması, suç işlemeye teşvik olup bu, kararın kuvvetlendirilmesine göre bir üst basamakta yer almaktadır. Zira ilerleyen kısımlarda da görülecek olduğu üzere kararın kuvvetlendirilmesinden söz edilebilmesi için teşvikteki durumdan farklı olarak tam anlamıyla karar vermis bir kimse söz konusu olmalıdır.

Ayrıca kişinin var olan düşüncesini aşan, başka bir karara yönelik fikirler ileri sürülmesi suretiyle kişinin düşüncesi dışında bir karara ulaşmasına neden olunması halinde artık suç işlemeye teşvikten değil, azmettirmeden bahsedilecektir. Dolayısıyla bir kimsenin malikanesini soymayı düşünen ve fakat bundan tam manasıyla emin olmayan bir kimseye malikane sahibinin hafta sonları malikanede olmadığı ve rahatlıkla malikaneye girilebileceği yönünde bilgi verip yanında bulunan malikanenin de ünlü bir iş adamına ait olduğu, oraya da girilebileceği yönünde mevcut düşünceye ek bir karar oluşturulması halinde artık failin aklındaki malikaneye girmesi bakımından manevi yardım etme, diğer ünlü iş adamının malikanesine girmesi açısından ise azmettirme gündeme gelecektir.

Kanaatimize göre bu konu kapsamındaki zorluk, suç işlemeye teşvik etmeyle azmettirme arasındaki farkın ne olduğu hususundan ziyade suç işlemeye teşvik etmeyle suç işleme kararının kuvvetlendirilmesi arasındaki farkın ne olduğu noktasında ortaya çıkacaktır. Zira azmettirme, ancak failde fiili işleme yönünde kararın bulunmadığı ve fakat faile yönelik olarak etkide bulunan kişi tarafından bu kararın oluşturulduğu yahut da "önemli şüpheleri ve kararsızllklarının söz konusu olduğu ve bunların giderildiği durumlarda gündeme geleceği" hallerde söz konusudur $^{72}$.

İlk bakışta suç işlemeye teşvikin de suç işleme kararının kuvvetlendirilmesi

71 Aydın, s. 185; Koca/Üzülmez, s. 489; Yaşar/Gökcan/Artuç, C. I, s. 1156; Nitekim Dönmezer/Erman'ın da suç işlemeye teşvik kapsamında kararsızlığı yahut da suçu işleme noktasında tereddütleri bulunan failden söz edilmediğine dikkat çekmek gerekir (Dönmezer/Erman, C.II, s. 532). Bununla birlikte azmettirme ile yardım etme arasındaki fark ortaya konulurken bunun fiil işlenmeden taraflar arasında bir anlaşmanın bulunup bulunmadığına indirgenmesi, bu şekilde bir etkenden söz edilmesi de (Centel/Zafer/Çakmut, s. 481) makul görünmemektedir.

72 Joecks, § 27 kn. 13; Andreas Hoyer, “Täterschaft und Teilnahme”, Systematischer Kommentar, Band 1, 7. Auflage, 2001, § 27 kn. 12. 
kapsamında anlaşılabileceği sonucuna ulaşılabilirse de aradaki ince çizginin düşünce ile karar arasındaki farkın belirlenmesi noktasında yer aldığı belirtilmelidir. Nitekim ilkinde henüz tam manasıyla karar vermemiş ve fakat ilgili suçu söz konusu kimseye karşı işlemeyi aklından geçiren bir kimse söz konusuyken ikincisinde zaten karara sahip olan bir kimsenin kararının pekiştirilmesi mevzu bahistir. Dolayısıyla bir kimseye söz konusu kararını icraata geçirmesine yönelik olarak fiili veya sözlü davranışlarda bulunma ve böylelikle kişinin kararlılığında belli bir oranda artışa neden olma, suç işlemeye teşvik olarak değil, suç işleme kararının kuvvetlendirilmesi olarak telakki edilecektir. Şu halde “...teşvik, failin suçu işleme kararını desteklemek ve onu kararını uygulamaya sürüklemektir..." ifadeleriyle Yargıtay Ceza Genel Kurulu kararında ${ }^{73}$ teşvik olarak anlaşılan belli bir karara sahip olan kişinin bu kararını uygulamaya sürüklenmesi, suç işlemeye teşvikten ziyade suç işleme kararının kuvvetlendirilmesi olarak anlaşılmalıdır.

Buradan da anlaşılmaktadır ki, bu iki kavram arasındaki belirsizlik, esasında her ikisinin de birbiriyle iç içe geçmiş olmasından kaynaklanmakta olup bu durum, aralarındaki farklılaştırmanın suniliğini göstermektedir. Gerçekten de Türk doktrini irdelendiğinde suç işlemeye teşvikle suç işleme kararının kuvvetlendirilmesi arasında net bir ayrımı sağlayacak kriterleri ortaya koyacak yeterli açıklamaların bulunmadığı dikkat çekmektedir ${ }^{74}$. Bunun nedeni, bu konu üzerinde yeterince çalışılmaması ya da düşünülmemesi değil, bilakis bu kavramlar arasında net bir ayrımın yapılmasını sağlayacak kriterlerin ortaya konmasındaki zorluk karşısında böyle bir ayrımın yapılmasının ne derece yerinde olduğu sorusunun varlığıdır. Öyle ki kanaatimize göre Alman doktrininde suç işlemeye teşvikten ayrıca söz edilmemesi, bilakis suç işleme kararının kuvvetlendirilmesi kapsamında telakki edilmesi de bu durumu doğrulamaktadır. Şu halde suç işlemeye teşvikten ziyade suç işleme kararının kuvvetlendirilmesinin ele alınması daha makul olacaktır.

\section{b. Suç İşleme Kararının Kuvvetlendirilmesi}

Manevi yardım etme, daha çok suç işleme kararının kuvvetlendirilmesi şeklinde gündeme gelmektedir ${ }^{75}$. Her ne kadar bir kimsenin, belirli bir kişiye yönelik olarak

73 YCGK 20.03.1978/1-19, K. 1978/93 (YKD, 1978, sy. 6, s. 1007); 23.10 .1989 tarih ve 1-235/302 sayıl1 kararında da Ceza Genel Kurulu, teşviki faildeki suç işleme kararının desteklenmesi ve pekiştirilmesi olarak nitelendirmiştir (Önder, C.II, s. 469). 
belirli bir suçu işleme yönünde bir kararı olsa da kişinin bu kararını pekiştirici her türlü söz yahut davranış, suç işleme kararının kuvvetlendirilmesi anlamına gelecektir $^{76}$. Bu kapsamda elbette ilgili davranışların failin kararına ne derece etki ettiğine ilişkin tespit bakımından bir sorunla karşılaşılmaktadır ki, bu da tamamen nedensellikle ilgili bir husus olarak görülebilir. Bilhassa suç işleme kararı olan bir kimsenin bu kararının sabit kılınmasının ne derece manevi yardım etme olarak nitelendirileceği oldukça muallak bir meseledir. Türk hukukunda çok fazla üzerinde durulmayan bu konuya ilişkin olarak Alman literatüründe üç farklı görüş ileri sürülmüştür:

Birinci görüşe göre nedensellik koşulundan vazgeçmek suretiyle her türlü etkilemeye dönük hareket üzerinde cezalandırılabilirlik kabul edilmekteyken ${ }^{77}$ ikinci görüşü temsilen bir kısım yazar, fiilin işlenmesi yönünde failde mevcut olan kararın sabit kılınması suretiyle manevi yardım etme imkanını, bu tür içsel etkilemelerin fiil üzerindeki nedensel katkısı tam anlamıyla yeterli görülmediğinden ve ispat bakımından birtakım zorlukların mevcut olmasından dolayı kural olarak reddetmektedir ${ }^{78}$. Ancak ikinci görüşteki bazı yazarlar, ilginç bir şekilde bu tür bir etkilemenin fiil üzerinde değil de fail üzerinde olduğu görüşünü benimseyerek yardım etmeden değil de azmettirmeden söz edilebileceğini, belki bu noktada bir tartışmanın yapılabileceğini

76 Dönmezer/Erman, C.II, s. 532; Önder, C.II, s. 469; Erdem, s. 214; Koca/Üzülmez, s. 489; Yaşar/Gökcan/ Artuç, C. I, s. 1156; Mahmutoğlu/Karadeniz, s. 933.

77 BGHSt 40, 307, 315; BGH NStZ 1999, s. 609, 610 (Murmann, § 27 kn. 130); Rengier, 45/88.

78 Nitekim Samson, bu etkileme kapsamındaki nedenselliğin neredeyse ispatlanamaz olduğuna, bununla ilişkili olarak kişinin bu tür durumlarda yardım eden olarak sorumlu tutulmasıyla "şüpheden sanık yararlanır (in dubio pro reo)" ilkesinin önemsenmediğine, oysa ki "şüpheden sanık yararlanır" ilkesi gereğince bu durumların en fazla teşebbüs aşamasında kalmış yardım etme olarak kabul edilebileceğine değinmiştir. Zira bu tür içsel anlamda etkilemenin söz konusu olduğu durumlarda manevi katkı ile netice arasında nedenselliğin kesin bir şekilde tespit edilebilir olmadığı belirtilmektedir (Samson, § 27 kn. 15). Roxin, bu görüşün haklı olarak mahkeme kararlarının yardım etmenin kapsamını genişletmesi nedeniyle ortaya çıkan endişelere işaret ettiğini ifade etmiş, fakat failin fiili işleme kararı üzerinde nedensel katkısının her daim ispatlanabilir olmadığı şeklindeki tespitin yerinde olmadığına, pekala failin içindeki bir takım şüphelerin giderilmesi veya faili cesaretlendirmek suretiyle fiili işlemesine yönelik olarak ek nedenler sağlayan yahut da fiilin içerdiği haksızlık yoğunluğunu artıran kişi bakımından nedenselliğin belirlenebilir olduğuna işaret etmiş̧tir (Roxin, AT II, § 26 kn. 208). Bununla birlikte Hruschka'nın failin fiili işleme kararının salt kuvvetlendirilmesinin failin fiilini işlemesini kolaylaştırma anlamında bir fayda sağlamayacağı ve dolayısıyla da yardım etmenin koşulunun gerçekleşmeyeceği yönündeki itirazına (Hruschka, JR 1983, s. 178; Bu görüşe hak verenler için Joecks, § 27 kn. 43; Kühl, § 20 kn. 226) karş1 olarak hem mantığa hem de kelime anlamına göre failin kararlılığının sabit kılınmasını sağlayacak bir hareket yapısının gerçeğe uygun olduğu, bu yardım etme şeklinin de failin kararını gerçekleştirmesi bakımından lehe bir durum sağladığı, bununla da riskin mağdurun aleyhine artırıldı̆̆ belirtilmiştir (Murmann, § 27 kn. 130). 
ileri sürmektedirler ${ }^{79}$. Nihayet bu kapsamda Alman mahkeme kararlarında benimsenen üçüncü görüş tarafından adeta konuya daha yüzeysel bir yaklaşım sergilenerek doğrudan manevi yardım etme kabul edilmekte ${ }^{80}$, bir tehlike suçu olarak kabul edilen yardım etmenin özellikle tehlikeye temel teşkil ettiğinden bahisle kapsamı oldukça geniş tutulmaktadır ${ }^{81}$. Literatürde de bu görüşü savunan yazarlara rastlanmaktadır. $\mathrm{Bu}$ yazarlara göre failin fiili işleme yönündeki kararında en ufak dereceli kuvvetlendirme dahimağdurnezdinderiskin artırılmasıolarakgörülmektedir. Kararınkuvvetlenmesinde etki olup olmadığı hususunda ispat sorununun bulunduğu yönündeki iddianın çok da yerinde olmadığını, zira bir fiili işlemeye karar veren kimsenin fiili işleme kararı ne kadar sıkı olursa olsun riskin az da olsa bir şekilde artırıldığını belirten bu yazarlara göre, failin kararında bu fiili işlemekten vazgeçme ihtimalinin sonlandırılması suretiyle da bir kuvvetlendirmeye neden olunabilmektedir ${ }^{82}$. Bu yazarlardan Roxin, kural olarak failin kararını salt etkilemek suretiyle yardım etmeyi mümkün görmektedir. Ancak bu kabul, söz konusu görüş sahiplerinin yardımsal katkıların nedenselliğinin zorunluluğundan vazgeçtikleri anlamına da gelmemelidir. Böylelikle bu görüş, yardım

79 Hruschka, failin fiili işleme kararının kuvvetlendirilmesi suretiyle manevi yardım etmeyi, Alman Ceza Kanunu'nda yer alan yardım etme düzenlemesinden hareketle yardımda bulunmanın faile değil de fiile dayalı olduğu gerekçesiyle sadece fiil üzerinde gerçekleşen bir etkilemenin yardım etme olarak kabul edilebileceği, fail üzerindeki bir etkileme hareketinin yardım etme olarak nitelendirilemeyeceği, bilakis azmettirme olarak kabul edilebileceği görüşünden bahisle failin fiili işleme kararının kuvvetlendirilmesi suretiyle manevi yardım etmeyi daha ilk baştan reddetmektedir. Fail üzerinde sadece fiili işlemesine yol açan nitelikteki hareketlerin azmettirme olarak kabul edildiğini belirten yazar, bunun dışında kararın kuvvetlendirilmesinin yürürlükteki hukuka göre cezasız kalacağını ileri sürmüştür (Hruschka, JR 1993, s. 178). Ancak Hruschka tarafından ileri sürülen yardım etmenin sadece fiil üzerinde söz konusu olabileceği şeklindeki bu tezin bir iddiadan öteye geçemeyeceği ve ispatlanmamış olduğu, aynı zamanda uygulanabilir olmadığı, zira faile teknik tavsiyelerde bulunulması ve fiilin işlenmesi için gerekli olan aracın sağlanmasının olayların gerçekleşmesi bakımından aynı şekilde failin üzerinde sadece manevi bir etki oluşturacağı, dolayısıyla da öncelikli etkilemenin fail üzerinde de olduğu belirtilerek ileri sürdüğü görüşe itiraz edilmiştir (Roxin, AT II, § $26 \mathrm{kn}$. 209). Nitekim Roxin 'in deyimiyle haklı olarak kanunda yer alan yardım etme şeklindeki düzenleme kapsamından ( $(27 \mathrm{StGB}$ ) dolaylı da olsa her türlü yardım hareketinin anlaşlabileceğine işaret edilmiştir. Elbette bu hareketlerin fiil üzerinde de dolaylı etkileri gündeme gelecektir. Nihayet Alman hukuku bakımından konuya ilişkin olarak ulaşılabilecek sonuç, mahkeme kararları ve doktrinde farklı olup mahkeme kararlarında bazı zamanlarda manevi desteklemenin fiilin işlenişi üzerinde hiçbir etkisi olmamasına rağmen kişinin yardım eden olarak cezalandırılması söz konusuyken doktrinde de fiilin işlenmesi kararının kuvvetlendirilmesine etki eden bir fiilin kural olarak mümkün olmadığı ileri sürülmektedir. (Roxin, AT II, § 26 kn. 209). Benzer şekilde Schünemann da bu görüşe fail ile fiili etkileme üzerinde sert bir ayrım yapılmasının çok sürdürülebilir olmadığı yönünde bir eleştiri getirmiş, kural olarak her şerikliğin fail üzerinde fiil bakımından etki ettiğini, fiilin işlenmesi yönündeki kararın kuvvetlendirilmesinin de fiil üzerindeki dolaylı etkilemenin sonuçları olması gerektiğini belirterek itirazda bulunmuş olsa da genel olarak bu tür etkileme hareketlerinin de düşünülmeden kabul edildiği şeklindeki eleştiriye de hak vermiştir (Schünemann, § $27 \mathrm{kn}$. 15; Bu görüşe hak verenler için bkz. Murmann, JuS 1999, s. 548, 551).

80 Bilgi için Geppert, s. 270; Schünemann, § 27 kn. 15.

81 Maurach/Gössel/Zipf, § 52 kn. 24; Joecks, § 27 kn. 9.

82 Murmann, JuS 1999, s. 551. 
etmenin cezalandırılabilirliği üzerinde hasıl olan genişlemenin bu şekilde sınırlandırılmasını da sağlamaya çalışmıştır ${ }^{83}$.

Kanaatimize göre daha evvel de üzerinde durulduğu üzere herhangi bir fïli işleme yönünde kesin karar vermiş bir fail söz konusu olsa da, kişinin bu kararında en düşük dereceli bir artışa yol açan kimsenin, işlenen fiil üzerinde manevi anlamda etkisinden söz edilmesi gerekir. Yani failin fiilinin işleniş sürecinde, bir başkası tarafından gerçekleştirilen davranış, failin kararının kuvvetlendirilmesi noktasında etkisiz gibi duruyor olabilir. Buna rağmen yardım etmenin failin fiili bakımından varlığından söz edilebilmesinin hiçbir şekilde aralarında doğal bir ilişkinin mevcudiyetine bağlı olmadığı, buna uygun olarak failde sağlam bir şekilde hasıl olan kararın dahi kuvvetlenmesi yoluyla failin fiili sonuna kadar sürdürmesine neden olacak şekilde yükselttiği ifade edilebilecektir ${ }^{84}$. Failin kararında düşük dereceli de olsa herhangi bir artışın olup olmadığg, ancak faili etkilemeye yönelik fiil veya sözlerin failin işlediği suçun haksızlık oranında bir artışa neden olup olmadığına göre olayın somut koşulları dikkate alınarak hakim tarafından somut belirtiler ortaya konmak suretiyle tespit edilebilir ${ }^{85}$. Dolayısıyla arka plandaki kişinin fiili işleyecek yahut da işlemekte olan failin kararı veya işlediği fiil üzerinde etki gösterip göstermediği, failin tipik hareketinin yoğunlaştırılması sonucunu ortaya çıkarması durumunda sorun teşkil etmeyecektir. Buna göre mağduru dövmekte olan bir faile alkış tutarak ve tezahürat yaparak dövmeye devam etmesinin istenmesi üzerine failin mağduru daha fazla veya daha sert bir şekilde dövmeyi sürdürmesi halinde açık bir şekilde manevi yardım etmeden söz edilecektir ${ }^{86}$. Yine genel olarak A'nın, fail konumundaki B'ye yardımda bulunacağına dair vaatte bulunması ${ }^{87}$ yahut da hırsızlık suçunun işlendiği esnada kapıda bekleyerek failin kendini güvende hissetmek suretiyle fiili işlemeye devam etmesi olaylarında, failin suç işleme kararı üzerinde nedensel anlamda bir etkinin oluşturulduğu hususunda bir şüphe bulunmamaktadır. Öyle ki bu durumlarda kişi, yardımsal nitelikte bir katkıda bulunmak suretiyle ya suçun işlenmesine "birlikte neden olan konumunda yer almakta" yahut da bir şekilde "suçun işlenmesine destek olmakta" $\mathrm{d}^{8} \mathrm{r}$.

83 Roxin, AT II, § 26 kn. 199.

84 Murmann, JuS 1999, s. 551; Murmann, Grundkurs StrR, § 27 kn. 130.

85 Geppert, s. 270.

86 Schünemann, § 27 kn. 14; Kühl, § 20 kn. 226; Roxin, AT II, § 26 kn. 200; Krey/Esser, § 32 kn. 1073; Heine/Wißer, § 27 kn. 15; Baunack, s. 118, 119; Maurach/Gössel/Zipf, § 52 kn. 25.

87 Heine/Weißer, § 27 kn. 12; Krey/Esser, § 32 kn. 1073.

88 Krey/Esser, § 32 kn. 1073. 
Ayrıca burada failin suç işleme kararının kuvvetlendirilmesinin kapsamının oldukça geniş olduğu, nitekim TCK md. 39 kapsamındaki davranışlardan herhangi birinin gerçekleştirilmesi durumunda da kararın kuvvetlendirilmesinden söz edilebileceği anlaşılmaktadır. Tüm bu hususlara rağmen bir kısım görüş sahibinin, bu yaklaşımla birlikte suç teşkil eden olayla ilgisi bulunmayan üçüncü kişinin sırf olay yerinde bulunması yahut da işlenen fiili salt uygun görmesi, tasvip etmesi durumlarının da manevi yardım etme olarak kabul edilmesi gibi bir tehlikenin ortaya çıkabileceği yönündeki eleştirilerine ${ }^{89}$ karşılık yapılan hareketin tasvip edilmesi, yani doğrudan fiili işleyen kişiye yönelik yapılan hareketin uygun görüldüğüne dair bir davranış sergilenmesinin de yukarıda ifade ettiğimiz üzere büyük oranda manevi anlamda yardım etme olarak telakki edilebileceği belirtilebilir ${ }^{90}$.

Yine olayla ilgisi olmayan üçüncü kişilerin, fiilin işlendiği esnada olay yerinde bulunmaları ve olayı izlemelerinin failin kararında bir pekişmeye neden olması veya en azından fiili işlemeye devam etme noktasındaki kararına etki etmesi argümanından hareketle yardım eden olarak sorumlu tutulmaları, gerçekten de ihmali hareketlerle icrai hareketlerin birbirine karışmasına yol açabilecek niteliktedir. Bu noktada cezalandırılabilir nitelikteki ihmali hareketlerle icrai hareketler arasındaki ayrımın ortaya konulması için salt hareketsizliğin cezaya tabi kılınmasının, sadece garantörlük konumunda ve keza garantörlük olmasa bile kanunda yardım etme yükümlülüğünün öngörüldüğü durumlarda söz konusu olabileceği ileri sürülebilir ${ }^{91}$. O halde olayla ve faille ilgisiz olan bir kimsenin, failin fiili işlediği esnada suç teşkil eden olayın seyircisi olması, o kişiyi işılenen suça yardım eden kılmayacaksa da olaya müdahale etmediği yahut da somut olayın koşullarına göre yetkili mercilere bildirmediği için kanunda özel olarak ihdas edilen yardım ve bildirim yükümlülüğünün yerine getirilmemesi yahut da suçu bildirmeme gibi suç tiplerinin faili olarak sorumlu tutulmasına sebep olacaktır. Bu anlamda bu suç tiplerinin kişilerin ihmali hareketle yardım eden olarak sorumlu tutulamayacak olmalarından kaynaklı cezalandırılabilirlik alanındaki boşluğu doldurma gibi bir işlevlerinin olduğu da belirtilebilir.

Buna rağmen olayla ilgisiz olmayan, failin yanında olay yerine giden ve fakat

89 Geppert, s. 270.

90 Baumann/Weber/Mitch/Eisele, § $26 \mathrm{kn}$. 100. Bununla birlikte hiçbir davranış sergilemeksizin, yani objektif anlamda katkı olarak tezahür etmeyecek şekilde salt işlenen fiilin uygun görülmesi veya tasvip edilmesi hakim görüşe göre yardım etme olarak görülmemektedir. Bkz. Baunack, s. 98; Schild, § 27 kn. 9.

91 Özgenç, s. 554; Erdem, s. 213; Artuk/Gökcen/Alşahin/Çakır, s. 677; Geppert, s. 270; Charalambakis, s. 637. 
fỉlin işlenmesi sürecine hiçbir şekilde müdahale etmeyen kişilerin, işlenen fiilden yardım eden olarak sorumlu tutulup tutulmayacakları, somut olayın koşullarına göre, bu pasif beklemenin failde ve de mağdurda oluşturduğu etki ve bu etkinin pasif şekilde bulunan kişi tarafından öngörülmenin yanı sıra kabullenilip kabullenilmediği dikkate alınarak belirlenecektir. Bu açıdan fiilin işlenmesi esnasında olay yerinden geçmekte olan ve bir an için olayı seyre dalan kişilerle bizatihi fiilin işlenmesi esnasında olayla ilgili şekilde failin yanında bulunan ve fakat aktif bir davranış sergilemeksizin bekleyen kişiler arasındaki fark gözetilmelidir. Fiilin işlenmesi esnasında olayla ilgili şekilde failin yanında bulunan ve fakat aktif bir davranış sergilemeksizin bekleyen kişilerin yardım eden olup olmadikları noktasında somut olayın koşulları özel olarak irdelenmeli, ex ante bir değerlendirme yapılarak sonuca ulaşılmalıdır ${ }^{92}$.

Failde söz konusu olan fiili işleme kararına răğmen mevcut olan düşük dereceli çekincelerin giderilmesi halinde yaygın görüşe göre failin fiili işleme kararının kuvvetlendirilmesi suretiyle manevi yardım etme söz konusu olabilir ${ }^{93}$ Bu kuvvetlendirme, açıkça veya sonuca yönelik bir hareket suretiyle gerçekleştirilmelidir. Bu bağlamda fiilin işlenmesine yönelik olarak failin kararının adeta sallantıda olduğu bir durumda kararının sağlamlaştırılmasına yönelik davranışlar, bu kararın ilk defa oluşmasına neden olan davranışlar olmadığından dolayı azmettirme olarak kabul edilmemekte, bilakis sadece yardım etme olarak telakki edilmektedir ${ }^{94}$. Buna göre C'den intikam almak istediği için C'ye karşı hırsızlık suçunu işlemeyi düşünen ve fakat C'nin bunu ortaya çıkaracağına dair içinde bazı şüpheleri bulunduğunu açıklayan B'ye yönelik olarak A'nın, C'nin evinde tek yaşadığını ve geceleri uykusunun çok ağır olduğunu, dolayısıyla gece evine girecek olursa C'nin kolay

92 "Sanığın, kasten öldürme suçunu gerçekleştiren diğer sanığın eylemine taraftar olmadığını gösterecek şekilde engelleyici bir söz söylemediği ve bu yönde davranışta bulunmadığı gibi, aksine olayın başından itibaren diğer sanığın yanında yer alması ve üzerindeki bıçakla maktule saldırması şeklindeki eylemleri göz önünde bulundurulduğunda, kasten öldürme suçunun işlenmesinden önce ve işlenmesi sırasında suçun icrasını kolaylaştırmak suretiyle diğer sanığa yardım ettiğinden hakkında 5237 sayılı TCK'nın 39/2-c maddesi uyarınca aynı maddenin 1. fikrasının uygulanması gerekir." YCGK, 19.03.2013, 81-91 - Akbulut, s. 666 , dpn. 2025.

93 Baunack, s. 98; Krey/Esser, § 32 kn. 1077; Roxin, FS-Miyazawa, s. 506; Roxin, AT II, $\S 26$ kn. 199, 200; Otto, § 22 kn. 56; Charalambakis, s. 635, 636; Geppert, s. 270; Thomas Weigend, "Grenzen strafbarer Beihilfe", FS-Nishihara, Nomos, Baden, 1998, s. 210, 211; Centel/Zafer/Çakmut, s. 482. Bu noktada kanaatimiz, şüphelerin ancak düşük dereceli olması durumunda manevi yardım etmeden söz edilebileceği yönündedir. Dolayısıyla şüphelerin derecesi, arka plandaki kişinin faildeki şüpheleri gidermesi noktasında azmettirmenin mi yoksa manevi yardım etmenin mi söz konusu olduğu hususunda önem arz etmektedir. Şu halde bazı kaynaklarda doğrudan şüphelerin giderilmesinin hiçbir ayrım yapılmaksızın bir bütün halinde manevi yardım etme kapsamında telakki edilmesi (Geppert, s. 268) yerinde değildir. 
kolay uyanmayacağını söylemesi üzerine B’nin bu önerilere uygun şekilde hırsızlık suçunu işlemesi durumunda artık yardım etmeden söz edilebilecektir. Zira bu olayda artık B'nin korunan hukuki değerler üzerindeki somut tehlikenin artmasına neden olduğu ifade edilebilecektir ${ }^{95}$.

Failin fiili işleme konusunda bir şüphe taşımaması ve fakat fiili işlemesine neden olan, kendi içinden kaynaklanan esas dürtünün yanına bir başka neden daha eklenmesine sebebiyet verecek şekilde bir katkıda bulunulması suretiyle failin kararının kesin hale getirilmesi durumlarında da nedensellik bağının varlığı kabul edilebilecek ve kişi, yardım eden olarak nitelendirilebilecektir ${ }^{96}$. Zira bu tür durumlarda failin fiili işleme kararının yardımsal katkı ile birlikte somut manevi etki gücü çerçevesinde riskin artırılması şeklinde "birlikte etki etmiş olduğu" var sayılabilir. $\mathrm{Bu}$ suretle fiilin işlenmesi sonucu gerçekleşen neticenin meydana gelmesine yol açan kararın kesin bir şekilde oluşmasına failin zaten var olan ancak kesin olmayan kararıyla birlikte etki eden olması hasebiyle netice bakımından dolaylı da olsa nedensel olduğu, bu anlamda -her ne kadar mutlaka gerekli olmasa daolmazsa olmaz (causa causae-est causa causati) bir nitelik taşıdı̆̆ ifade edilebilir ${ }^{97}$. Nitekim Alman mahkeme kararlarının bazılarında bu tanımlamaya uygun kararların varlığı da görülmektedir. Söz konusu mahkeme kararlarına göre bir tanığa onun boşanma davası esnasında verilecek olan gerçek dışı beyanlar karşısında sessiz kalabileceği yönünde vaatte bulunan kişi ${ }^{98}$; daha önceden kürtaj yaptırmaya karar vermiş olan gebe kadına bu fiili mutlaka gerçekleştirmesi için ayrıca para veren kimse $^{99}$; eşini öldürmeye karar vermiş olan bir adama, kafasındaki eşini öldürme fikrini yerine getirmesi durumunda kendisiyle evleneceği garantisini veren adamın sevgilisi olan kadın ${ }^{100}$; yaptıkları bu katkıyla neticenin kesin olarak gerçekleşmesine yol açacak şekilde failin fiili işleme kararını pekiştirdiklerinden, hukuki değerlerin ihlal edilmesinin yoğunlaştırılması sonucuna yol açan, bu anlamda da netice

95 Otto, § $22 \mathrm{kn} .56$.

96 Geppert, s. 270; Roxin, AT II, § 26 kn. 200; Schünemann, § 27 kn. 14; Joecks, § 27 kn. 43; Hoyer, § 27 kn. 14.

97 Roxin, AT II, § 26 kn. 200; Uwe Murmann, “Zum Tatbestand der Beihilfe”, JuS 1999, s. 552; Baunack, s. 99; Weigend, s. 209; Heine/Weißer, § 27 kn. 15; Fiile yönelik olarak "sağlam” bir şekilde kararlılık, her daim kararından vazgeçme ihtimalini de içerdiğinden riskin yükseltilmesi fiilin ölçülebilir bir şekilde desteklenmesi koşuluyla sınırlandırılmıştır (Kühl, § 20 kn. 227, dpn. 362b; Weigend, s. 210; Krey/Esser, azmettirme olduğunu belirterek eleştiri getirmiştir. Bkz. Krey/Esser, kn. 1077.

98 HRR 1938 Nr. 629 (Joecks, § 27 kn. 13).

99 HRR 1939 Nr. 1275 (Joecks, § 27 kn. 13)

100 RGSt 73, 52 (Joecks, § 27 kn. 13; Seher, s. 795). 
bakımından nedensel olduğunda hiçbir şüphe bulunmayan katkılar ortaya koyduklarından manevi anlamda yardım edenlerdir. Zira faili birtakım hareketleriyle kışkırtan kişinin, neticenin mağdur üzerinde isabet etme ihtimalini artırdığ 1 , neticenin somut olarak gerçekleşmesini kuvvetlendirdiği açık olup bu çerçevede yardım eden olarak cezalandırılması söz konusu olabilecektir ${ }^{101}$.

Ancak önemle belirtmek gerekir ki, doktrinde bir kısım görüş tarafından her ne kadar failde var olan içgüdüsel nedene bir neden daha ekleyen kişi, yardım eden olarak nitelendirilecek olsa da, faile fiili işlemesi için yeni bir neden oluşturan kişinin, failin fiili işlemesinde bu nedeni kendine esas alması halinde azmettiren olarak sorumlu tutulacağ1, zira bu tür durumlarda artık yeni bir fiil işleme kararından bahsedilebileceği belirtilmektedir ${ }^{102}$. Ancak kanaatimize göre doktrindeki bu görüş pek makul görünmemektedir. Nitekim azmettirmeye ilişkin yapılan açıklamalarda da açıklandığı üzere azmettirme, failde bir suç işleme kararının oluşturulması olup failde var olan karara yeni bir neden eklenmesi demek değildir. Yani hırsızlık suçunu sadece borcunu ödemek için işlemeyi düşünen faile çalacağı parayla borcunu ödemek yerine bir dükkan açmasının daha doğru olacağını söyleyen kişi, failin hırsızlık suçuna temel teşkil eden bu nedenini değiştirmesi durumunda sırf bu nedensel değişiklikten dolayı azmettiren olarak nitelendirilemeyecek, olsa olsa manevi yardım eden olarak kabul edilebilecektir.

Bunların dışında failin fiili icra etmeden evvel başka bir ek neden oluşturmaksızın ya da failde şüphe bulunmamasından kaynaklı olarak herhangi bir şüphe giderimi söz konusu olmaksızın, sadece failin işlediği fiilin yoğunluk derecesinin artmasına yol açacak şekilde kışkırtıldığı durumlarda da kararının pekiştirilmesinden ve bu kapsamda da fiilin neticesinin haksızlık içeriğinin artırılmasından dolayı manevi anlamda yardım etme gündeme gelebilecektir ${ }^{103}$. Ancak failin kararının mevcudiyetinin sağlam olduğu hallerde nedensellikten, daha doğrusu riskin hukuken uygun görülecek nitelikte artırılmasından söz edilemeyeceğinden bu tür bir manevi yardım etmeden

101 Roxin, AT II, § 26 kn. 200.

102 Maurach/Gössel/Zipf, § 52 kn. 9; Nitekim Charalambakis, failde fiili işlemesi bakımından ek bir sebep daha oluşturarak şüphelerini gideren kişiyi, suçu birlikte belirleyen olarak kabul edip bu kişinin azmettiren olduğu sonucuna ulaşmıştır (Charalambakis, s. 635, 636); Ancak Roxin, bu tür bir hareketin haksızlık içeriğinin faile eş bir cezalandırmayı beraberinde getirebilecek nitelikte fiile neden olmadığını, sadece destekleme niteliğinde bir hareketin mevcut olduğunu, faildeki fiilin işlenmesi yönündeki kararın sağlamlaştırılmasına ihtiyaç bulunmayan, bilakis kararı zaten sağlam, net olan bir failin tamamen fiili işleme yönündeki motivasyonunu güçlendirici olan hareketlerin yardım etme niteliğinde olduğunu vurgulamıştır (Roxin, AT II, § 26 kn. 200).

103 Heine/Weißer, § 27 kn. 15; Baunack, s. 119; Roxin, FS-Miyazawa, s. 506; Roxin, AT II, § 26 kn. 200. 
bahsedilemeyecektir ${ }^{104}$. Bu çerçevede henüz sona erdirilmemiş olan içgüdüsel süreç bakımından failin kararının gerçek anlamda kuvvetlendirilmesi ve bu suretle hukuki değerlerin ihlal edilmesi ihtimalinin yükseltilmesi zorunlu görülmüştür ${ }^{105}$.

Başkasının fiilinin salt tek taraflı olarak bilinmesi yahut herhangi bir katkıda bulunmaksızın tasvip edilmesi, bu fiille ilgili düşünce beyan edilmesi, bu fiile müsamaha gösterilmesi, fiilin onaylanması veya işlenen/işlenmekte olan fiile sempatiyle bakılması şeklinde faile dayanışma arz edecek nitelikteki durumlarda kişinin yardım eden olarak nitelendirilip nitelendirilemeyeceği açısından ise Türk doktrininde teşvik etme veya kararı kuvvetlendirme olduğundan bahisle manevi yardım etme olacağı görüşü hakimken ${ }^{106}$ gerek genel itibariyle Alman mahkeme kararlarında ${ }^{107}$-ki yardım etmenin çerçevesini oldukça geniş tutan BGH'nın her ne kadar eski tarihli olsa da bu konuda da ilginç kararlarının var olduğu görülmektedir ${ }^{108}$ gerekse Alman literatüründe hakim görüş ${ }^{109}$ tarafından bu tür salt tasvip veya dayanışma tarzı ifadelerin beyan edilmesi, daha önceden anlaşılan fiilin işlenme kararının yoğunluğu üzerinde bir etki oluşturmayacağından bahisle sadece faili memnun edici bir duruma yol açacağından hareketle cezalandırılabilir yardım etme için yeterli kabul edilmemiştir. Buna göre evinde marihuana yetiştirilmesine göz yuman kişinin uyuşturucu madde suçuna yardım eden olarak kabul edilemeyeceği, zira salt işlenen bir fiilin uygun görülmesinin, tasvip edilmesinin garantör

104 Heine/Weißer, $\S 27$ kn. 15; Baunack, s. 128, 129.

105 Heine/Weißer, $\S 27$ kn. 15.

106 Dönmezer/Erman, C. II, s. 533.

107 BGH NStZ 2010, s. 225 (Krey/Esser, § 32 kn. 1070); BGH NStZ 1998, s. 662 (Kühl, § 20 kn. 226); BGH NStZ 2007, s. 37 (Joecks, § 27 kn. 14).

108 Öyle ki BGH, eşine yönelik öldürme planlarını bilmesine rağmen bu kişiyle sevgililik ilişkisini sürdürdüğü için failin suç işleme kararını kuvvetlendirdiği yönünde bir karar verilmiştir (BGH NJW 1950, s. 118 Joecks, § 27 kn. 9). Aynı şekilde polisi yaralayarak kaçarak evine giren bir kimse ile yakınlık kuran bir kişi de polisin kasten yaralanmasına yardım eden olarak sorumlu tutulmuştur (BGH NJW 1975, s. 49 - Joecks, $\S 27 \mathrm{kn} .9)$.

109 Schünemann, § 27 kn. 14; Baunack, s. 160; Heine/Weißer, § 27 kn. 15; Heinrich, kn. 1322; Hoyer, $§ 27$ kn. 14; Kühl, § 20 kn. 226; Weigend, s. 209; Joecks, § 27 kn. 44; Maurach/Gössel/Zipf, § 52 kn. 10; Roxin, AT II, $\S 26$ kn. 202. Roxin de benzer şekilde bu hareketlerle failin fiili işleme kararının ne şüphelerin giderilmesi durumunda olduğu gibi sabit kılındığını ne ek bir sebep daha eklenerek daha geniş temellere konulduğunu ne de hukuki değerlerin ihlal edilmesini yükseltmekteki gibi daha da yoğunlaştırıldığını belirtmiştir. Keza Roxin, bu tür durumların yardım etme olarak cezalandırılamayacağının Alman Ceza Kanunu'nun 140'ıncı paragrafında düzenlenen "Suçu ödüllendirme ve uygun bulma" başlıklı suç tipinden anlaşıldığını, nitekim bu suç tipi kapsamında yalnızca çok sınırlı sayıda suç tipi bakımından bir suçun işlenmiş olmasının tasvip edilmesinin ceza tehdidi ile karşı karşıya kalmasının söz konusu olduğunu ifade etmiştir (Roxin, AT II, § 26 kn. 201) Söz konusu suç tipi kapsamında yer verilen suçlar işlendikten veya cezalandırılabilir bir şekilde işlenmeye teşebbüs edildikten sonra ödüllendirilir ya da kamu barışını bozmaya elverişli bir şekilde alenen, bir toplantıda veya yazı yayarak bu suçu onaylayan kişinin üç yıla kadar hapis cezası veya adli para cezası ile cezalandırılacağı hükmüne yer verilmiştir. 
yükümlülüğünün şartlarıyla birlikte ihmal suretiyle yardım etmenin sınırlarına geçemeyeceği, sorumluluğu beraberinde getirmeyeceği belirtilmiştir ${ }^{110}$.

Otto, kesin olarak karar verilen bir fiile yönelik olarak alkış, onay veya dayanışma teşkil edecek nitelikte beyanların söz konusu fiiller bakımından karar verilmesini sağlamayacağı yönündeki eleştiriye hak vermiş, salt fikirsel anlamda bir beyanatın yardım etme olarak nitelendirilemeyeceğini, yolu kapatan karı kürekle alarak yolu açmaya çalışan bir kimseye "Bravo!" diyerek bağıran bir kimsenin söz konusu yolun açılması bakımından hiçbir şekilde yardımda bulunmuş olmayacağını belirterek manevi yardım etme bakımından da yardım edenin hareketinin failin fiilini objektif olarak kolaylaştırması veya desteklemesi noktasında birtakım belirtilerin bulunmasının zorunlu olduğunu ifade etmiştir ${ }^{111}$. Benzer hususun salt düşüncenin beyan edilmesi bakımından da geçerli olduğu, sırf düşünce beyanının da yardım etme olarak nitelendirilemeyeceği, öyle ki salt bir kimsenin işlediği fiile sempati beslenmesi yardım etmeye ilişkin düzenleme kapsamında telakki edilmiş olsa ve cezalandırılabilir görülmüş olsaydı bu defa hukuk devleti açısından oldukça sorunlu bir durumun ortaya çıkmasına zemin hazırlanmış olacağı vurgulanmışıır ${ }^{112}$.

Bu noktada önemli bir hususa daha dikkat çekmek gerekir. O da şu ki, Alman doktrininde failin yanında hareketsiz bir şekilde bulunan kişinin kendisini ele vermeyeceği ve kendisine engel çıkarmayacağı düşüncesiyle suç teşkil eden hareketlerini devam ettirmeye yönelik olarak motive olan failin varlı̆̆ durumunun da hareketsiz bir şekilde yanında bulunan kişinin yardım eden olarak sorumlu tutulması sonucunu ortaya çıkarmayacağına vurgu yapılmaktadır ${ }^{113}$. Bu durum, iki temel argümanla açıklanmaktadır. Birincisi, bağlılık kuralından hareketle BGH tarafından verilen kararda da işaret edildiği üzere failin yanında bulunan kişinin de bu durumun bilincinde olması, yani en azından failin yanında hareketsiz bir şekilde bekleyişi karşısında gerektiğinde failin lehine olaya müdahil olacağı düşüncesiyle fiili işleme kararının daha da güçlendiğinden hareket ettiğinin farkında olması ve buna rağmen beklemeye devam etmesi gerekmektedir. İkincisi ise her ne kadar kişinin pasif

110 İlgili mahkeme kararları için bkz. Joecks, $§ 27$ kn. 14, dpn. 36.

111 Otto, $\S 22 \mathrm{kn} .56$.

112 Schünemann, § 27 kn. 14; Baunack, s. 160.

113 Roxin, AT II, § 26 kn. 205; Krey/Esser, kn. 1077; Seher, s. 795; Heinrich, kn. 1322; Joecks, § 27 kn. 9. Nitekim olay yerinde pasif bir şekilde bekleyen kişilerin yardım eden olarak sorumlu tutulması gerektiğini kabul eden Alman mahkeme kararlarının eleştirilmesine hak veren Charalambakis, ihmali hareketlerin cezalandırılmasını garantör olma şartına bağlayan Alman Ceza Kanunu'nun 13'üncü paragrafına işaret etmiştir (Charalambakis, s. 637, 638). 
durmasının failin fiilinin türüne ve yöntemine ilişkin cesareti üzerinde tek taraflı olarak etkili olduğu belirtilebilecekse de bekleyen kişinin ihmali bir davranışı söz konusu olduğundan kanunen hangi hallerde ihmali davranışın cezalandırılabileceğinin belirlendiği, bu çerçevede salt ihmali davranışın kişiyi garantör kılmaması ve bu bağlamda cezalandırılabilme şartlarının oluşmaması nedeniyle kişinin yardım eden olarak sorumlu tutulmasının mümkün olmamasıdır ${ }^{114}$. Nitekim bir kimsenin, yanındaki kişinin işlediği suç esnasında o kişiye manevi desteğe yol açacak davranışlardan sakınma gibi bir yükümlülüğün getirilmesinin ne çerçevede kapsamı belirli bir durum olduğu da tartışmaya açık olacaktır. Buna karşılık arka plandaki kişinin olay yerinde bulunma amacının failin, karşı tarafın meşru savunma teşebbüsünde bulunması gibi birtakım zorluklarla karşılaşması durumunda mağduru korkutmak ya da faile destek olmak ise bu defa failin fiili işlediği esnada sessiz bir şekilde beklese bile durumda değişiklik olacaktır ${ }^{115}$. Bu koşullar altında suça iştirak eden kişi, fiil planı kapsamında amacı yerine getirirse ve failin yükünü hafifletirse bunun da manevi yardım etmeyi temellendirebileceği ifade edilmektedir ${ }^{116}$.

En nihayetinde failin fiilini etkilemeye yönelik şeriklik türü davranışları arasında azmettirme, suç işlemeye teşvik, suç işleme kararının kuvvetlendirilmesi ve nihayet failin fiiline etkisizlik sonucu akim kalmış yardım etme şeklinde bir kademeli ilişkiden söz edilebilir. Buna göre arka plandaki kişinin sözlü yahut fiili davranışının faile yahut failin fiiline etki derecesine göre arka plandaki kişinin azmettiren olarak nitelendirilmesi mümkün olabileceği gibi akim kalmış yardım etme cezasız kaldığından cezalandırılmaması da gündeme gelebilecektir ${ }^{117}$. Dolayısıyla incelemenin bu kademeli ilişki göz önünde bulundurularak gerçekleştirilmesi daha makul olacaktır.

\section{c. Fiilin İşıenmesinden Sonra Yardımda Bulunulacağına Dair Vaat}

Manevi anlamda yardım etme kapsamındaki davranış türlerinden bir diğeri, fiilin işlenmesinden sonra yardımda bulunulacağına dair vaattir. Fiilin işlenmesinden evvel fiilin işlenmesinden sonra faile yardımda bulunulacağına dair söz verilmesi, teminatta bulunulması, fiili işleyecek olan failin cesaretinin artırılmasına sebebiyet verir ${ }^{118}$.

114 Roxin, AT II, $\S 26$ kn. 205.

115 Joecks, § 27 kn. 9; Maurach/Gössel/Zipf, § 52 kn. 27.

116 Baunack, s. 155, 159; Maurach/Gössel/Zipf, § 52 kn. 27; Joecks, § 27 kn. 9.

117 Akim kalmış yardım etmenin cezasızlığına ilişkin tartışma ve açıklamalar için bkz. Muhammed Demirel, Suça İştirakte Bağlılık Kuralı, Doktora Tezi, İstanbul 2017.

118 Dönmezer/Erman, C. II, s. 532; Önder, C.II, s. 469; Erdem, s. 214; Artuk/Gökcen/Yenidünya, s. 673; Centel/Zafer/Çakmut, s. 482; Zafer, s. 479; Mahmutoğlu/Karadeniz, s. 933. 
Hazırlık hareketi mahiyetindeki bu davranışlarla zaten fiil üzerinde hakimiyet kurulamayacağından bu şekilde vaatte bulunan bir kimsenin fail olarak sorumluluğundan bahsedilemezse $\mathrm{de}^{119}$ yardım eden olarak sorumluluğu gündeme gelebilecektir ${ }^{120}$. Fakat fiilin işlenmesinden sonrasına ilişkin olarak kafasında bazı soru işaretleri bulunan faile yardım vaadinde bulunulmasıyla birlikte bu soru işaretlerinin giderilmesi durumunda, fiilin işlenmesinden sonra yardımda bulunulacağına dair vaadin, failin suç işleme kararının kuvvetlenmesine neden olacağı açıktır ${ }^{121}$. Zira bu tür destek hareketleri, failin tespit edilip ortaya çıkarılması riskini azaltmaktadır ${ }^{122}$. Buna rağmen suç işleme kararının kuvvetlendirilmesinin yanı sıra fiilin işlenmesinden sonra yardımda bulunulacağına dair vaat şeklindeki davranış türünün öngörülmesinin ne anlam ifade ettiği ortaya konulmalıdır. Fiilin işlenmesinden sonra yardımda bulunulacağına dair vaadin, yardım etme olarak kabul edilebilmesi için failin fiili işleme kararı üzerinde herhangi bir etki oluşturmasına gerek olmayıp failde fiili işlerken fiil sonrası bir beklentiye kapılmasına yol açması da yeterlidir ki bu durumda manevi yardım etmeden söz edilebilecektir. Bununla birlikte failin hiçbir şekilde umursamadığı, önem atfetmediği yardım vaadi, yalnızca akim kalmış yardım etme sınırları içerisinde cezasız kalacaktır.

Tam bu noktada önemle belirtmek gerekir ki, bir kimsenin faile karş1 fiilin işlenmesinden sonra yardımda bulunacağına dair bir vaatte bulunması ve bu vaadin failde bir beklentiye yol açmasının da ötesinde failin suç işleme kararını kuvvetlendirmesi halinde artık TCK md. 39 kapsamındaki davranışlardan birkaçının aynı anda gerçekleşmesinden söz edilecektir -ki bu, madde kapsamındaki yardım etme hareketleri seçimlik olarak gösterildiğinden pekala mümkündür ${ }^{123}$ - ve bu durum, TCK md. 61 kapsamında cezanın belirlenmesinde dikkate alınacaktır ${ }^{124}$.

119 Kayıhan İçel/Füsun Sokullu-Akınc//İzzet Özgenç/Adem Sözüer/Fatih S. Mahmutoğlu/Yener Ünver, Suç Teorisi, 3. Bas1, Beta, İstanbul 2004, s. 383.

120 Baumann/Weber/Mitch/Eisele, $\$ 26$ kn. 100.

121 Önder, C.II, s. 469; Nitekim Türk doktrininde bazı yazarlar tarafından hem suç işleme kararının kuvvetlendirilmesinde hem de suçun işlenmesinden sonra yardımda bulunulacağına dair vaatte bulunulmasında faile cesaret verilmesinden söz edilmesi de (Bkz. Yaşar/Gökcan/Artuç, C. I, s. 1156) bu iki tür yardım etme davranışın iç içeliğini açıkça ortaya koymaktadır

122 Maurach/Gössel/Zipf, § 52 kn. 29; Roxin, AT II, § 26 kn. 201.

123 Mahmutoğlu/Karadeniz, s. 919.

124 Koca/Üzülmez, s. 492; Mahmutoğlu/Karadeniz, s. 920. Nitekim Yargitay 1. Ceza Dairesi'nin 27.09.2006 tarih ve 3885/3053 sayılı kararında sanığın, suçta kullanılan tüfeği sanık M.K.'a vermesi, eylemin icrası için birlikte olay yerine gitmesi, beklemesi, olaydan sonra tüfeği M.K.'dan alıp saklamasında, olaya yardım düzeyinin yüksekliği gözetilmeden TCK 39. maddenin uygulanmasında cezanın alt sınırdan tayini suretiyle eksik ceza verilmesi kanuna aykırı görülmüştür. Bkz. Yaşar/Gökcan/Artuç, C. I, s. 1159, dpn. 1412. 
Alman doktrininde "failin suç sonrasında tespit edilmesini engellemeye yönelik hareketlerde bulunma vaadi"nden söz edilirken Türk Ceza Kanunu'nda "fiilin işlenmesinden sonra yardımda bulunulacağına dair vaatte bulunma" şeklindeki davranış türünün ihdas edilmiş olması, davranış türünü daha somut hale getirmiştir. Zira Alman doktrinindeki failin suç sonrasında tespit edilmesini engellemeye yönelik hareketlerde bulunma vaadi, sadece failin tespitini önlemeye dair bir vaadi içerirken Türk hukukunda öngörülen fiilin işlenmesinden sonra yardımda bulunma vaadi, failin tespit edilmesini engellemeye yönelik vaadi de kapsamında bulunduracak niteliği haiz olup daha geniş bir içeriğe sahiptir. $\mathrm{Bu}$ minvalde Türk hukukunda vaadin konusu hususunda herhangi bir sınırlandırma yapılmamıştır $^{125}$. Önemli olan failin yapılan vaatten etkilenmiş olması ve vaade dayalı hareket etmiş olmasıdır. Şu halde A’nın, B'ye hırsızlık suçunu işlerken tespit edilmesini engelleyecek özel bir elbise vaadi ${ }^{126}$, gece vakti büyük bir mağazadan eşya çalma planları yapan D’nin, işlenen suç sonrası olası soruşturmada olay esnasında tramvayda olduğunu ispat edebilmek adına kendi akbilini fiil işlediği saatte eve dönüşte kullanması için arkadaşı C'ye teslim etme vaadi ${ }^{127}$, faile fiile işledikten sonrası için yurt dışına kaçması için uçak bileti satın alınacağı ve kaçış işılemlerinin gerçekleştirileceğinin belirtilmesi ${ }^{128}$ şeklindeki failin suç sonrasında tespit edilmesini engellemeye yönelik hareketler mevzu bahis olabileceği gibi failin yakalanması ve cezaya mahkum edilmesi halinde cezaevindeyken ailesinin her türlü bakım masrafının karşılanacağına yönelik diğer davranışlar bu kapsamda telakki edilebilir ${ }^{129}$.

Etkisini fiilin işlenmesinden sonra gösterecek olan yardımda bulunulacağına dair vaadin, mutlaka fiilin işlenmesinden evvel veya en azından fiilin işlendiği esnada yapılması gerekir. Yani yardım etme için, söz konusu vaadin suç tamamlanmadan evvel yerine getirilmesi şart değildir. Bu minvalde örneklerde de görüldüğü üzere faile vaat edilen yardımın, mutlaka yerine getirilmiş olması da şart değildir. Zira bu kapsamda cezaya layık görülen davranış, henüz işlememiş yahut da işlemeye başlamış fakat henüz tamamlamamış olan faile yönelik olarak failin fiili işlemesi hususunda olumlu bir etki göstermiş olan suç tamamlandıktan sonra yardımda bulunulacağına dair vaadin kendisidir. Bu anlamda bizatihi söz konusu vaatte bulunulması da manevi

125 Yaşar/Gökcan/Artuç, C. I, s. 1157.

126 RGSt 8, 267 (Maurach/Gössel/Zipf, § 52 kn. 29).

127 BGH NJW 1951, s. 451 (Maurach/Gössel/Zipf, § 52 kn. 29).

128 Geppert, s. 267, dpn. 25.

129 Yaşar/Gökcan/Artuç, C. I, s. 1157. 
anlamda yardım etme için yeterli olacaktır ${ }^{130}$.

Bu noktada fiilin işlenmesinden sonra failin yakalanmasını, tutuklanmasını veya hakkında hükmolunan mahkumiyet kararını infazını engelleyecek şekilde imkan săglama vaadinde bulunan kişi, esasında suçun işlenmesinden sonra yardımda bulunma vaadinde bulunarak işlenen suça manevi anlamda yardım eden konumunda olacak, bununla birlikte suçun işlenmesi halinde, bu şekilde işlenen suçun manevi anlamda yardım edeni olan kişinin bu vaadini yerine getirmesi halinde artık TCK md. 283 hükmünde öngörülen "Suçluyu Kayırma Suçu” suçunun faili olacaktır. Buna göre henüz suç işlenmeden suçluyu kayırma vaadinde bulunan bir kimsenin, suç işlendikten sonra gerçekten de söz konusu vaadini yerine getirmesi durumunda hem TCK md. 283 hükmünün faili hem de önceki suçun yardım edeni olacaktır ${ }^{131}$. Burada üzerinde durulması gereken esas husus, bu kişinin tek fiille hem fail, hem de yardım eden olmasıdır. Yani böyle bir durumda görünüşte içtima kuralları kapsamında asli norm-tali norm kuralları gereğince failliğin şerikliğe asliliğinden hareketle kişinin sadece TCK md. 283 hükmünden fail olarak sorumlu tutulması yoluna gidilemez. Zira burada önce bir suçun işlenmesi halinde sonrasında failin yargılanmasının engelleneceğine dair vaatle failin kararının kuvvetlendirilmesi suretiyle manevi yardım hareketi gerçekleştirilmekte, zamansal olarak failin suçu işlemesinin ardındansa söz konusu vaadin yerine getirilmesi suretiyle bu defa TCK md. 283 'te düzenlenen suçun fail konumunda işlenmesi söz konusudur. Dolayısıyla bu iki hareket, tek fiil olarak tezahür etmemekte, farklı zamanlarda gerçekleştirilen hareketlerin bir görünüm şekli olarak ortaya çıkmaktadır. Şu halde bu kişi hem fail hem de yardım eden olarak sorumlu tutulacaktır.

Bununla birlikte TCK md. 283 hükmünde yer alan "Bu suçun, üst soy, alt soy, eş, kardeş veya diğer suç ortă̆ı tarafindan işlenmesi halinde, cezaya hükmolunmaz." şeklindeki şahsi cezasızlık sebebi dikkate alındığında bu kişi, önceki suçun yardım edeni olduğundan fail olarak sorumlu tutulduğu TCK md. 283 kapsamındaki suçtan dolayı cezalandırılmayacak, geriye yalnızca önceki işlenen suça yardım etmeden kaynaklı sorumluluğu kalacaktır. Diğer bir ifadeyle fiilin işlenmesinden sonra failin yakalanmasını, tutuklanmasını veya hakkındaki hükmolunan mahkumiyet kararını infazını engelleyecek şekilde imkan sağlama vaadinde bulunan üst soy, alt soy, eş,

130 Aydın, s. 178; Zafer, s. 479; Yaşar/Gökcan/Artuç, C. I, s. 1157.

131 Özbek/Doğan/Bacaksız/Tepe, s. 525; Yaşar/Gökcan/Artuç, C. I, s. 1157. 
kardeş veya diğer suç ortağ konumundaki kişi bu vaadini yerine getirdiği takdirde, hakkında sadece yardım etmeden ceza verilebilecektir ${ }^{132}$.

Tüm bu anlatılanlardan sonra TCK md. 281 hükmü kapsamında ihdas edilen “Suç Delillerini Yok Etme, Gizleme veya Değiştirme Suçu”na da değinmekte yarar bulunmaktadır. Bu suç hükmüne göre "Gerçeğin meydana çıkmasını engellemek amacıyla, bir suçun delillerini yok eden, silen, gizleyen, değiştiren veya bozan kişi ... cezalandırılır. Kendi işlediği veya işlenişine iştirak ettiği suçla ilgili olarak kişiye bu fikra hükmüne göre ceza verilmez." Bu kapsamda kişinin kendi işlediği veya işlenişine iştirak ettiği suçla ilgili olarak kendisi hakkında bu suç hükmüne göre ceza verilmeyeceği öngörülerek bir başka kişinin işlediği suçun delillerinin yok edilmesi, gizlenmesi veya değiştirilmesi suretiyle yardım eden sıfatıyla iştirak edilmesi halinde bu suç düzenlemesi bakımından da şahsi cezasızlık sebebine yer verilmiş, böylelikle yardım eden kişinin bu suç hükmüne binaen fail olarak sorumlu tutulmasının önüne geçilmiştir. $\mathrm{Bu}$ kapsamda yardımsal katkıda bulunacak olan kişinin henüz fiil işlenmeden yahut da işlenirken, daha doğrusu henüz fiil tamamlanmadan önce söz gelimi delillerin ortadan kaldırılmasına yönelik bir vaatte bulunması, sadece fail tarafından işlenen suça manevi yardım etme olarak kabul edilecekken ${ }^{133}$ bilakis bu şekilde bir vaade binaen fiilin tamamlanmasının ardından delillerin gizlenmesi, yok edilmesi veya değiştirilmesi suretiyle failin işlediği fiilin ortaya çıkarılmasını engellemeye yönelik davranışlar, işlenen suça manevi yardım etmenin yanı sıra bağımsız bir suç tipi olan TCK md. 281 çerçevesinde cezalandırılmayacaksa da ${ }^{134}$ bu durum, kişinin önceki suça yardım eden olarak sorumlu tutulmasına da engel teşkil etmeyecektir. Yani TCK md. 283 için yapılan açıklamalar, büyük ölçüde bu suç açısından da geçerlidir.

132 Alman doktrininde failin fiili gerçekleştirme kararının kuvvetlendirilmesi yoluyla manevi anlamda yardım etmenin söz konusu olabileceğini reddeden yazarların bu fikirlerinin benimsenmesi halinde, bu tür hareketlerin her birinin "Suçluyu Kayırma" olarak anlaşılacağı aşikardır. Ancak mağdur tarafından tanınmaması için faile yüz maskesi veya kamuflaj elbisesi sağlayan yahut da polis tarafindan yapılan araştırmalarda ortaya çıkması muhtemel delilleri saklayan kişinin hareketinin netice bakımından kural olarak nedensel kabul edileceği, zira bu katkılarda bulunan kişinin bu sayede ya faildeki tereddütleri ortadan kaldıracağı ya da failin fiilin işlemeye yönelik eğilimini yükselteceği açıktır (Schünemann, § 27 kn. 13; Roxin, AT II, § 26 kn. 201). Zira kişinin bu katkıları olmasaydı failin neticeye ulaşmak için ya başka önlemler alması yahut da fiilin işleniş yöntemi üzerinde bir takım değişiklikler yapması gerekecekti. Ancak sırf yardım edenin bu katkıları sayesinde failin ne başka önlemler almasına ne de fiili işleme yönteminde bir değişiklik yapmasına gerek kalmıştır (Roxin, AT II, § 26 kn. 201).

133 Otto, § 22 kn. 56; Geppert, s. 270; Roxin, AT II, § 26 kn. 199; Weigend, s. 210, 211; Yaşar/Gökcan/Artuç, C. I, s. 1156.

134 Yaşar/Gökcan/Artuç, C. I, s. 1157. 


\section{d. Suçun İşlenmesi Hususunda Yol Gösterme}

Yardım etme hareketlerinden suçun nasıl işleneceği hususunda yol gösterme, fiilin işleneceği yer, bu yerde bulunan alarm sistemi, mağdurun eve sürekli gelip gittiği yol gibi genel davranışları, faile ev sahibinin evde olmadığı anı bildirme, fiilin daha hızlı nasıl işlenebileceği yahut da kesin sonuca nasıl ulaşılabileceği gibi hususlar hakkında faile detaylı bilgi verme ${ }^{135}$, çelik kasayı açmasını sağlayabilecek olan sayısal şifreler konusunda bilgilendirme veya suikastı en iyi nasıl gerçekleştirebileceği yönünde akıl hocalığ 1 yapma ${ }^{136}$, fiilin nerde daha iyi bir şekilde işlenebileceği ya da silahın nasıl kullanılacağını anlatma ${ }^{137}$ gibi teknik anlamda yol gösterici nitelikteki hareketlerle gerçekleştirilebilirr ${ }^{138}$. Yol gösterici nitelikteki bu tür hareketler bakımından fiilin somut işlenme türünün ve usulünün değişmesine yol açan kişilerin tıpk1 fail gibi netice bakımından nedensel nitelikte bir katk1 sağladıklarında ve bu katkının manevi bir niteliği haiz olduğuna hiçbir şüphe bulunmamaktadır ${ }^{139}$. Keza yardım eden kişinin bu türden bir katkısıyla netice arasındaki nedensel bağlantının varlığının kolaylıkla tespit edilebileceği de belirtilmektedir ${ }^{140}$.

Nitekim Alman mahkemelerinin de bu konuda çoğunlukla pek tartışmalı kararlar vermediği görülmektedir. Krallık Yüksek Mahkemesi'nin o dönem mevcut olan Düello suçu kapsamında düelloda kullanılacak silahın türü üzerine kurulan danışma konseyi tarafindan karar verilmesi ${ }^{141}$ veya öldürme suçunun amaca uygun şekilde işlenmesi hususunda tavsiyelerde bulunulmasi ${ }^{142}$ yahut da daha yakın zamanlarda sigorta şirketini aldatma amacında olan bir kişiye otomobilini nasıl ateşe vereceğinin anlatılmas $1^{143}$ gibi olayların her birinde manevi yardım etme örnekleri vuku bulup ortaya konulan bu tavsiye niteliğindeki fikirsel katkılar netice bakımından nedensel addedilmiştir.

135 Kühl, § 20 kn. 225; Rengier, 45/87; Roxin, AT II, § 26 kn. 198; Krey/Esser, § 32 kn. 1072; Maurach/ Gössel/Zipf, § $52 \mathrm{kn} .7$.

136 Hoyer, § 27 kn. 11; Maurach/Gössel/Zipf, § 52 kn. 23.

137 Seher, s. 795.

138 Baunack, s. 97; Schünemann, § 27 kn. 12; Alman Mahkeme kararları için Kühl, § 20 kn. 225; Joecks, § 27 kn. 7.

139 Dönmezer/Erman, C. II, s. 533; Schünemann, § 27 kn. 12; Otto, § 22 kn. 54.

140 Baunack, s. 97. Hoyer, teknik anlamda yol gösterici nitelikteki hareketler ifadesini tercih etmemektedir. Zaten yazarın ayrıldığı nokta da terminolojik bakımdan olup bunun dışında görüşleri benzer bir nitelik taşımaktadır (Hoyer, § $27 \mathrm{kn} .11$ ).

141 RGSt 13, 265 (Roxin, AT II, § 26 kn. 198; Schünemann, § 27 kn. 49).

142 RGSt 73, 52 (Roxin, AT II, § 26 kn. 198).

143 BGHR StGB $\S 27$, Abs. 1, Hilfeleisten, Nr. 2 (Roxin, AT II, $\S 26$ kn. 198). 
Bu kapsamda değinilmesi gereken hususlardan biri, 765 sayılı TCK' da yer alan "suçun ne suretle işleneceğine müteallik talimat vererek..." ifadesindeki "talimat" ibaresidir. Her ne kadar doktrinde kanunda kullanılan bu ifadenin, yol gösterme yerine kullanıldığ 1 kabul edilmekteyse de $^{144}$ bunun, gerek sözlük kullanımında ${ }^{145}$ gerek günlük kullanımında, gerekse de hukuki kullanımda bir öneri veya akıl vermekten ziyade muhatabı belli bir konuda davranmak noktasında adeta zorunlu tutacak nitelikteki sözler olarak nitelendirilebileceği açıktır. Bu minvalde bilhassa Askeri Ceza hukukunda yaygın bir şekilde kullanıldı̆̆ 1 görülen "Talimat" kelimesinin kullanıldığı normlar irdelendiğinde talimat vererek astların belirli şekillerde hareket etmelerine sebebiyet veren üstün, herhangi bir suçun işlenmesi durumunda bu suça yardım eden olarak sorumluluğu değil, bilakis azmettiren olarak sorumluluğu gündeme gelecektir. $O$ halde asta verilen talimatın, üstün azmettiren olarak sorumlu tutulmasına neden olması, talimatın yol göstermenin de ötesinde bir kavram olduğunu göstermektedir. Tüm bu izahattan sonra 765 say1lı TCK' da yol göstermeye karşılık kullanılan "talimat" ifadesinin oldukça şüpheli olduğunu ${ }^{146}$, nitekim 5237 sayılı TCK'da söz konusu ifade yerine açıkça "yol gösterme"nin tercih edildiğini ve bu suretle şüphelerin de ortadan kaldırıldığını ifade etmek gerekir.

\section{Değerlendirme ve Sonuç}

Tüm bu bilgilerden ve açıklamalardan sonra yapacağımız değerlendirme, esasında bu çalışmada temel olarak altı çizilen hususların tekrarlanması olacaktır. $\mathrm{Bu}$ çerçevede en çok önem arz eden meselelerden biri, yardım etmenin de faillikteki suç sistematiğine benzer bir sistematiğin ortaya konulmuş olmasıdır. Buna göre yardım etmenin tipikliği kapsamında yer alan maddi unsuru altında failin kasıtll ve hukuka aykırı olarak işlenmiş fiili ile "inceleme konumuz olan yardım etme hareketleri" yer alacakken manevi unsuru altında çifte şeriklik kastı yer alacaktır. Böylelikle Alman hukukunda zaten bilinen bu sistem, Türk

144 Önder, C.II, s. 469.

145 Nitekim Türk Dil Kurumu'nun Büyük Türkçe Sözlüğü’nde yer alan ifade şu şekildedir: “1. Yönerge: Demir Bey’den beklenilen talimat gelmişti. -R. H. Karay. 2. ask. Görevin gerektirdiği türlü hizmetlerin başarıyla yürütülmesi için kumandan, başkan veya daire başkanları tarafindan verilen, o hizmetle ilgili sorumluluk, düzen ve ilkeleri içine alan buyruklar.” Bkz. http://www.tdk.gov.tr/index.php?option=com_ bts\&arama=kelime\&guid=TDK.GTS.5a184b6179c143.85087725.

146 Mülga kanun dönemindeki doktrinde talimat vermenin maddi yardım mı yoksa manevi yardım mı olduğu konusunda bir takım tartışmalar yapılmışsa da (Dönmezer/Erman, C. II, s. 533) asli iştirak olduğu konusunda hiçbir görüşün ileri sürülmemiş olması da oldukça ilginç karşılanacak bir husustur. 
hukukunda da bilinir hale gelecek, yardım etmenin incelenmesi biraz daha basite indirgenmiş olacaktır.

$\mathrm{Bu}$ kapsamda belirtilmesi gereken ikinci husus, failin işlediği fiile yönelik olarak gerçekleştirilen katkının kendisi maddi olmasına rağmen etkisinin manevi olduğu durumlarda artık maddi anlamda yardımdan değil, manevi anlamda yardımdan söz edilecek olmasıdır. Yine üçüncü olarak faile suçun işlenmesini mümkün kılacak şekilde araç temin edilmesi, "fiilin icrasını kolaylaştırma" kapsamında telakki edilebilecektir. $\mathrm{Bu}$ minvalde kanunda ayrıca "araç sağlanması" unsuruna yer vermenin gerekli olup olmadığı da şüpheli hale gelecektir.

Dördüncü olarak gözcülük yapılması suretiyle işlenen suça iştirak üzerinde durulmalıdır. Suç işlenirken gözcülük yapılması halinde bu katkının hangi iştirak türüne karşılık geldiğinin tespit edilmesi, somut olayın koşullarının dikkate alınmasına bağlıdır. Bu çerçevede evvela müşterek failliğin koşullarının oluşup oluşmadığ irdelenecek, failliğe ilişkin şartların gerçekleşmemesi halinde, yani fiilin işlenişi üzerinde hakimiyetin bulunduğunun tespit edilememesi halinde bu defa yardım etme üzerinden bir inceleme yapılacaktır. $\mathrm{Bu}$ değerlendirme, fiilin işlenmesi için verilen kararın icra ediliş biçimi, olay öncesinde, esnasında ve sonrasında gerçekleştirilen davranışların birlikte dikkate alınması suretiyle yapılır.

Son olarak TCK'da "fiilin işlenmesinden sonra yardımda bulunulacağına dair vaatte bulunma" şeklindeki davranış türünün ihdas edilmiş olmasının, davranış türünü daha somut hale getirdiği ifade edilebilir. Bununla bağlantılı olarak fiilin işlenmesinden sonra failin yakalanmasını, tutuklanmasını veya hakkındaki hükmolunan mahkumiyet kararının infazını engelleyecek şekilde imkan sağlama vaadinde bulunan kişi, işlenen suça manevi anlamda yardım eden konumunda olacak; suçun işlenmesi halinde ise, vaadin yerine getirilmesiyle birlikte artı TCK md. 283 hükmünde öngörülen "Suçluyu Kayırma Suçu”nun faili olacaktır. Sonuç olarak da görünüşte içtima kuralı uygulanarak failliğin şerikliğe asliliği kuralı gereği kişinin sadece TCK md. 283'ten fail olarak sorumlu tutulması yoluna gidilmeyecek, hem işlenen suça yardım etme, hem de sonradan TCK md. 283'e faillik söz konusu olacaktır. Nitekim burada aynı anda işlenmiş tek bir fiil bulunmayıp bir vaat ve bu vaadin yerine getirilmesi şeklinde iki ayrı fiil mevzu bahistirir ${ }^{147}$

147 Görünüşte içtima kuralları için bkz. Muhammed Demirel, "Karar Analizi Tehlike Suçları-Zarar Suçları Arasındaki İlişkinin İçtima Kuralları Kapsamında Değerlendirilmesi”, Prof. Dr. Füsun SokulluAkıncı'ya Armağan, İÜHFM, C. LXXI, S. 1, 2013, s. 1479-1489. 


\section{Kisaltmalar}

$\begin{array}{ll}\text { Alm. CK } & \text { : Alman Ceza Kanunu } \\ \text { AT } & \text { : Allgemeiner Teil } \\ \text { BGH } & \text { : Bundesgerichtshof } \\ \text { BGHSt } & \text { : Entscheidungen des Bundesgerichtshofs in Strafsachen } \\ \text { C. } & \text { : Cilt } \\ \text { CD } & \text { : Ceza Dairesi } \\ \text { dpn. } & \text { : dipnot } \\ \text { E. } & : \text { Esas } \\ \text { FS } & : \text { Festschrift } \\ \text { GÜ } & : \text { Galatasaray Üniversitesi } \\ \text { K. } & : \text { Karar } \\ \text { kn. } & \text { : Kenar Notu } \\ \text { RGSt } & : \text { Entscheidungen des Reichsgerichts in Strafsachen } \\ \text { StGB } & : \text { Strafgesetzbuch } \\ \text { TCK } & : \text { Türk Ceza Kanunu } \\ \text { YCGK } & : \text { Yargitay Ceza Genel Kurulu } \\ \text { YKD } & \text { : Yargitay Kararlari Dergisi }\end{array}$

\section{Kaynakça}

Akbulut, Berrin: Ceza Hukuku Genel Hükümler, 4. Bası, Adalet, Ankara 2017.

Artuk, Mehmet Emin/Gökcen, Ahmet/Yenidünya, Caner: Ceza Hukuku Genel Hükümler, Adalet Yayınevi, 10. Bas1, Ankara 2016.

Artuk, M. Emin/Gökcen, Ahmet/Alşahin, M. Emin/Çakır, Kerim: Ceza Hukuku Genel Hükümler, 11. Baskı, Adalet, Ankara 2017.

Aydın, Devrim: Türk Ceza Hukukunda Suça İştirak, Yetkin Yayınları, Ankara 2009.

Baumann, Jürgen: “Täterschaft und Teilnahme”, JuS 1963, s. 125-138.

Baumann, Jürgen/Weber, Ulrich/Mitsch, Wolfgang/Eisele, Jörg: Strafrecht Allgemeiner Teil, 12. Auflage, Verlag Ersnt und Werner Gieseking, Bielefeld 2016.

Baunack, Martina Grenzfragen der strafrechtlichen Beihilfe, Duncker \& Humblot, Berlin 1999.

Charalambakis, Aristoteles: "Zur Problematik der psychischen Beihilfe”, FS-Roxin, 2001, 625-639.

Centel, Nur/Zafer, Hamide/Çakmut, Özlem: Türk Ceza Hukuku Genel Hükümler, 9. Bası, Beta, İstanbul 2016.

Demirel, Muhammed: "Karar Analizi Tehlike Suçları-Zarar Suçları Arasındaki İlişkinin İçtima Kuralları Kapsamında Değerlendirilmesi”, Prof. Dr. Füsun Sokullu-Akıncı'ya Armağan, İÜHFM, C. LXXI, S. 1, 2013, s. 1479-1489.

Demirel, Muhammed: Suça İştirakte Bağlılık Kuralı, (Doktora Tezi), İstanbul 2017.

Dönmezer, Sulhi/Erman, Sahir: Nazari ve Tatbiki Ceza Hukuku, Beta Yayınları, C. II, 10. Bası, İstanbul 1997. 
Erdem, Mustafa Ruhan: "Yeni TCK'da Faillik ve Suç Ortaklı̆̆ı", HPD 2005, S. 5.

Evik, Vesile Sonay: Suça İștirakte Yardım Edenin Ceza Sorumluluğu, Oniki Levha, İstanbul 2010.

Geppert, Klaus: "Die Beihilfe”, Jura 1999, s. 266-274.

Gropp, Walter: Strafrecht Allgemeiner Teil, 4. Auflage, Springer 2015.

Gülşen, Recep: "Bir Fer'i Maddi İştirak Şekli OLarak İş veya Vasıta Tedariki (TCK m. 65/II)", Prof. Dr. Çetin Özek Armağanı, GÜ Yay., İstanbul 2004.

Hafızoğulları, Zeki/Özen, Muharrem: Türk Ceza Hukuku Genel Hükümler, 2. Bası, US-A Yayıncılık, Ankara 2010.

Haft, Fritjof: Strafrecht Allgemeiner Teil, 9. Auflage, C.H. Beck, München 2004.

Hakeri, Hakan: Ceza Hukuku Genel Hükümler, 20 Baskı, Adalet, Ankara 2017.

Heine, Günther/Weißer, Bettina: "Täterschaft und Teilnahme”, Schönke/Schroeder Strafgesetzbuch Kommentar, 29. Auflage, Verlag C.H. Beck, München 2014.

Herinrich, Bernd: Strafrecht Allgemeiner Teil, 4. Auflage, Kohlhammer, Tübingen 2015.

Hilgendorf, Eric/Valerius, Brian: Strafrecht Allgemeiner Teil, 2. Auflage, C.H.Beck, München 2015.

Hoffmann-Holland, Klaus: Strafrecht Allgemeiner Teil, 3. Auflage, Mohr Siebeck, Tübingen 2015.

Hoyer, Andreas: "Täterschaft und Teilnahme”, Systematischer Kommentar, Band 1, 7. Auflage, 2001.

Hruschka, Joachim: “Alternativfeststellung zwischen Anstiftung und sog. psychischer Beihilfe”, JR 1983, 177181.

İçel, Kayıhan/Sokullu-Akıncı, Füsun/Özgenç, İzzet/Sözüer, Adem/Mahmutoğlu, Fatih Selami/Ünver, Yener: Suç Teorisi, Beta Yayınları, 3. Bası, İstanbul 2004.

Jescheck, Hans-Heinrich/Weigend, Thomas: Lehrbuch des Strafrechts, Allgemeiner Teil, 5. Auflage, Duncker\&Humblot, Berlin 1996.

Joecks, Wolfgang: "Täterschaft und Teilnahme", Münchener Kommentar zum Strafgesetzbuch, Band 1, §§ 1-51 StGB, Verlag C.H. Beck, München 2003.

Koca, Mahmut/Üzülmez, İlhan: Ceza Hukuku Genel Hükümler, 10. Baskı, Seçkin, Ankara 2017.

Krey, Volker/Esser, Robert: Deutsches Strafrecht, Allgemeiner Teil, 5. Auflage, Stuttgart 2012.

Kühl, Kristian: Strafrecht Allgemeiner Teil, 7. Auflage, Vahlen, München 2012.

Mahmutoğlu, Fatih Selami/Karadeniz, Serra: Türk Ceza Kanunu Genel Hükümler Şerhi, Beta, İstanbul 2017.

Maurach, Reinhart/Gössel, Karl Heinz/Zipf, Heinz/Dölling, Dieter/Laue, Christian/ Renzikowski, Joachim: Strafrecht Allgemeiner Teil, Teilband 2, 8. Auflage, C.F.Müller, 2014.

Murmann, Uwe: Grundkurs Strafrecht, 3. Auflage, C.H. Beck, München 2015.

Murmann, Uwe: “Zum Tatbestand der Beihilfe”, JuS 1999, s. 548-553.

Osnabrügge, Stephan A.: Die Beihilfe und ihr Erfolg, Ducker\&Humblot, Berlin 2002.

Otto, Harro: “Anstiftung und Beihilfe”, JuS 1982, s. 557-566.

Önder, Ayhan: Ceza Hukuku Genel Hükümler, Filiz Kitabevi, C. II-III, 2. Bası, İstanbul, 1992.

Özbek, Veli Özer/Doğan, Koray/Bacaksız, Pınar/Tepe, İlker: Türk Ceza Hukuku Genel Hükümler, 8. Bask1, Seçkin, Ankara 2017.

Özgenç, İzzet: Türk Ceza Hukuku Genel Hükümler, 13. Bası, Seçkin, Ankara 2017.

Özkan, Halid: Ceza Hukukunda Azmettirme, Adalet, Ankara 2013.

Rengier, Rudolf: Strafrecht Allgemeiner Teil, 7. Auflage, C.H. Beck, München 2015.

Roxin, Claus: "Was ist Beihilfe?", FS-Miyazawa, 1995, s. 501-517.

Roxin, Claus: Strafrecht Allgemeiner Teil, Band II, C.H. Beck, München 2003. 
Satzger, Helmut: "Teilnehmerstrafbarkeit und "Doppelvorsatz"”, Jura 2008, s. 514-523.

Schild, Wolfgang: "Täterschaft und Teilnahme”, in Nomos Kommentar, Band 1, 4. Auflage, Baden, 2013.

Schulz, Joachim: “Anstiftung oder Beihilfe”, JuS 1986, s. 933-942.

Schünemann, Bernd: “Täterschaft und Teilnahme”, Leipziger Kommentar Strafgesetzbuch, Band 1, $\S ~ 1-51$ StGB, 12. Auflage, De Gruyter, 2010.

Seher, Gerhard: "Grundfälle zur Beihilfe”, JuS 2009, s. 793-797.

Stoffers, Kristian F. : "Streitige Fragen der psychischen Beihilfe im Strafrecht”, Jura 1993, s. 11-17.

Weigend, Thomas: “Grenzen strafbarer Beihilfe”, FS-Nishihara, Nomos, Baden, 1998.

Yaşar, Osman/Gökcan, Hasan Tahsin/Artuç, Mustafa: Yorumlu-Uygulamalı Türk Ceza Kanunu, C. I, 2. Bask1, Adalet, Ankara 2014.

Yıldız, Ali Kemal: 5237 Sayılı Türk Ceza Kanunu, İstanbul Barosu Yayınları, İstanbul 2007.

Zafer, Hamide: Ceza Hukuku Genel Hükümler, 6. Bası, Beta, İstanbul 2016. 
